Historic, Archive Document

Do not assume content reflects current scientific knowledge, policies, or practices. 



\section{IRIST TULIPS.}

Last year we offerd for the first time in the United States, six varieties of Irish Grown Tutips and promised those who purchased them a grace, fragrance, combinations of $\mathrm{col}$. oring and size hitherto unknown. Although the weather last Spring was somewhat unfav. orable for best results, 1 hese Irish Grown Tulios fuily came up to the expectations of those who planted them, and as they are somewhat later in blooming than Dutch Grown sorts, the weather was more settled and allowed them to attain to great perfection. These Tulips are not only perfectly distinct from the Holland Grown varieties, but are in many respects superior. They do not come into flower until nearly the end of May, after the glory of the Hyacinth. Daffodil and Early Tulips has departed. They are of taller growth, larger size and more brilliant colors; besides, all are sweetly scented. The year's experience gives us great confidence in recommending the sorts we catalngued last year. We have added to the list four new Gesneriana, that will prove acquisitions.

Billietiana. (16 inches.) Bright yellow and crimson

Columbus. (I4 inches.) Velvety crimson, striped with gold

Didieri Alba. (14 inches.) Glistening, silvery white. Sweet pea fragrance

Golden Eagle. ( 12 inches.) Brilliant yellow. Very s we t scented

Macrospeila. (12 inches.) Glist. ening sca.let, with deep zone ot black and yellow. Siveet pea fragrance.

Shand on Bells. (it inches.) Pink and creamy yellow in bud, deep magenta when open

FOUR GESNERIANA TULIPS.

Rosea Cœrulea. (1S inches.) Bright rose with blue base

Rosea Alba Corulea. ( 18 inches.)

Very bright rose, blue and

white base in the form of a

Maltese Cross

Doz, Glistening bright rose, white base

. 554.50 Firefly. (16 inches.) Orange, with green and gold base, the form of a star. In full sunlight this is a blaze of color

FOUR EXTRA FINE SINGLE LATE TULIPS.

These four varieties come in to bloom practically at the same time and are about one height, 18 inches. "When planted together they make a bed that attains nearer to the "Ideal" than anything else. We hope all lovers of the beautiful will plant a mass of these to crown the Spring garden of 1903 .

Golden Beauty. Golden yellow. Golden Crown. Yellow, edged with crimson Crimson, biaci Centre Crimson, biack Isabelia. Bright rose, fiaked with white
Doz. $\quad 100$

$22 \$ 1.25$

.15

$.2 n$

\section{BOSTON PUBLIC GARDENS.}

We continue to supply our customers the same quality and varieties of Tulips as used by Mr. Doogue in the Boston Public Gardens. And for the benefit of those who may wish to secure a similar effect another se:ason, we give, in part, Mr. Doogue's arrangements of kinds :-

No. 1. Joost van Vondel, white, centre mass. Joost van Vondel, cherry red, flaked with white, for No. 2. Rose Luisante, deep rose, centre mass. Stanley, rich claret, for edging.

Ni. 3. Couleur de Cardinal, rich bronze red, centre mass. Cottage Maid, pink and white, for edging.

No. 4. Proserpine, rich dark rose, centre mass. Royal Standard Gold Striped, scarlet, striped with yellow, for edging. Other $\mathrm{sp}: c^{\circ}$.lly beautiful sorts are:-Vermillion Brilliant, Prince of Austrid, Thomas Moore, White Swan, Kaizersl.. 3... and Standard Royal, all elsewhere described in this catalogue.

\section{JAPANESE FERN BALIS.}

This beautiful Japanes' novelty has already become very popular. The centre is moss, covered in an inge nious manner with fern roots. To start irito growth, place the ball in a pail of water until thoroughly we through, hang in a window and water two or three times a week. After watering, growth beyins in a few days, and the ball sonn becomes a mass of beautiful, green, lace-like foliage. Each, 75 cents, net.

\section{EXAMPLES.}

FAULKNER Farm, Brookline, Mass., JUNE 5 , IgO1.

JOSEPH BRECK \& S INS,

Gents:- The bulbs for forcing, of which I buy several thousand every fall, were especially satisfac. tory this year, being large and well ripened. They all fo-ced splendidly and gave good results, particularly the Hyacinths which were the best I have had for several years.

Very truly yours,

David WeIR, SuPt.
Goddard Ave, BRoOKLine, Mass. JOSEPH BRECK \& SONS,

DEAR SIRS:- I am pleased to state that the goods purchased of you at different times proved very satisfactory to me. I can recommend your goods and methods to friends without scruple.

Yours respectfully,

KenNhth Finlaison. 


\section{IDSEPH BRECK \& SONS Nos. 47 to 54 No. Market Si}

WSEPH BREUK \& SUNS,

\section{ORDER SHEET.}

Correct fllling of orders and prompt shipment will be greatly facilitated by its ise.

Date,

IgOI

Name,

Post Office,

AMOUNT ENCLOSED.

Express or Post

Office Order, $\}$

Postal Note, - $\$$.

Draft,

Express Office,

(If different from Post Office.)

Cash or Stamps, $\varnothing$

State,

County,

Total, 


QUANTIT

SEE SPEGIAL OFFERS. 


\section{ESTABLISHED IN 1822.}

\section{...ANNUAL...}

\section{DESCRIPTIVE CATALOGUE}

.....OF......

\section{Dutch Bulbs, Flower Roots, ETC.}

FOR AUTUMNN PLANTING.

\section{JOSEPH BRECK \& SONS, (CORPORATION)} Importers, Growers and Dealers in

Flower, Vegetable, Field and Grass Seeds.

New England Agricultural Warehouse, Woodenware and Seed Store.

Nos. 47 to 54 NORTH MARKET STREET, BOSTON, MASS., U. S. A. 


\section{INDEX.}

ADONIS

Alliums .............. 5

Amaryllis............. I5

Anemones............15, 16

A pples..............25

Arum ................ 6

BABIANAS ......... 6

Barley .............28

Begonia de Lorraine aud Caledonia

Bellows

Blackberries

Bone Cutters

Bone for Poultry ......28

Brodixa ............. 6

Brooders .............. 30

Bruslies, Whitewash....29

Buckwheat ..........28

CALLA LILI. . ....... I6

Calochortus ............ 6

Camassia ...........16

Caponizing Instruments . 29

Carbolic. ...........28

Cart, Farm............ 31

Cereal Chicken

Feed, Breck's....28

Charcoal

.28

Chinese New Year's Lily I3

Chionodoxa........... I6

Christmas Rose........ I8

Clover, cut; and

Clover Meal....28

Collections, page 2 of

Cover..21

Coichicum

16

Copperas ...........? 8

Crocus ............... I 7

Crown Imperials ........ I 7

Cutters, Clover and Feerl 30

Currants ........... 26

Cyclamen $\ldots \ldots \ldots \ldots \ldots$. 7

DALIMATION POIVDER 28

Death to Lice......... 28

Decorative House Plants. 3

Dicentra, Dielytra...... 7

EGG FOOD ..........28

Eiggs, Nest...........29

Erauthes............. I

Erythronium .......... I 7

FARMER'S HANDY

WAGON $\cdot 3$ I
Fence, Farm

Fence, Lawn .........

Fern Balls, Page 2 of cover

Fertilizers.

Fibre, Tropik..........22

Food, Flower

Fountains, Poultry....29

Freezias

Fritillaria (see Crown

Imperials) I $7,1 \mathrm{~S}$

Fruit Trees.

Fumigators

GLADIOLI

Glasses, Hyacinth

Gloxinias

Gooseberries .

Grass Seed

Grapevines...........26

Ground Beef Scraps ....28

HEATERS.

Hedge Plants.........25

Helleborus Niger

(Xmas Rose)..... 8

Hemp.............28

Herbaceous Plants .....27

House Plants.......... 3

Hyacinths ......... 6, 7

INCUBATIOR .........

Insecticides .........22

Iris $\ldots \ldots \ldots \ldots \ldots \ldots$

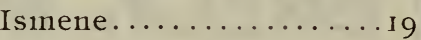

Ixia

JONQUILS (see

Narcissi).11, 12

Knives, French Poultry .29

LACHENALIAS ........ I9

Lawn Fence............

Lawn Grass Seed .......24

Leg Bands............29

I ilies ........ I3, I4, I 5, 16

MADEIRA VINES . . . . I 9

Manna, T. P. C. Cliick ...28

Mats, Hot Bed .......22

Meal, Poultry and Swine 28

Mica Grit. . . . . . . . . 28

Millet............28

NARCISSI .... IO, II, I 12,13

Nerine .............. I 5

Nest Eggs............29

Netting, Poultry .........

OIL OF TAR..........29
Ornithogalum .......... I9

Oxalis.................

Osster Shells ..........28

PAONIES........... 19

Paint Lice ........... 29

P. D. Q. Powder.......28

Peaches ...............25

Pears.............. 25

Peas..................28

Plant Department.25, 26, 27

Plaster................ 29

Plows ................. 32

Pots and Pans, Flower...23

Poultry Supplies ....28, 29

Powder, Condition......28

Powder, Lice.......28, 29

QUINCES ...........25

RANUNCULUS .... . 20

Raspberries ..........26

Roofiug Material ......29

Roses ........................ 25

SAUCERS $\ldots \ldots \ldots \ldots 23$

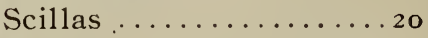

Shade \& Ornamental Trees25

Shelf, Window ........23

Snowdrops ........... $=0$

Snowflakes............ 20

Soil, Potting .......... 21

Sorghum .............28

Sparaxis ............

Spiræa .............20

Spratt's Poultry Food ...28

Stands, Plant.........23

Strawberries..........26

Sulpho-Napthol .......29

Sundries ...........2:

Sunflower ...........28

TOBACCO DUST

AND STEMS. 29

Tubs, Plant .........24

Tulips, Page 2 of

cover, $7,8,9,10$

Trillium ..........2

Tropæolum ...........20

Tritelia ............2

Tritonia.............

WAGON, Farmer's Handy 3 I

Wheat ...........28

Wheelbarrows .... $\ldots 3^{2}$

X-ZALIA ...................

Zephyranthes ......... 15 


\section{JOSEPH BRECK \& SONS,}

(CORPORATION.)

47 to 54 North Market St.,

BOSTON,

MASS. 
<smiles>C=CC</smiles> 


\section{DECORATIVE PLANTS FOR THE HOUSE. \\ BEGONIA GLOIRE DE LORRAINE.}

No flowering plant equals this for beauty and continuous bloom. Without special care it will flower throughout the entire winter and in such a profuse manner as almost to co iceal the foliage with its wealth of salmon-rose colorel blossoms.

We hare had a large and rery fine stock of this univers $1 \mathrm{f}$ frorite grown $e=$ pecially for our trade. The plants are all thioroughly healthy and clean; all are of blooming size and will give good satisfaetion. In $2 \frac{1}{2}$ inch pots, $25 \mathrm{cts}$. each; $\$ 2.50$ doz. In 4 inch pots, $35 \mathrm{cts}$. each $\$ 3.50$ doz. In 6 inch pans, $\$ 1.00$ each, $\$ 10.00$ doz.

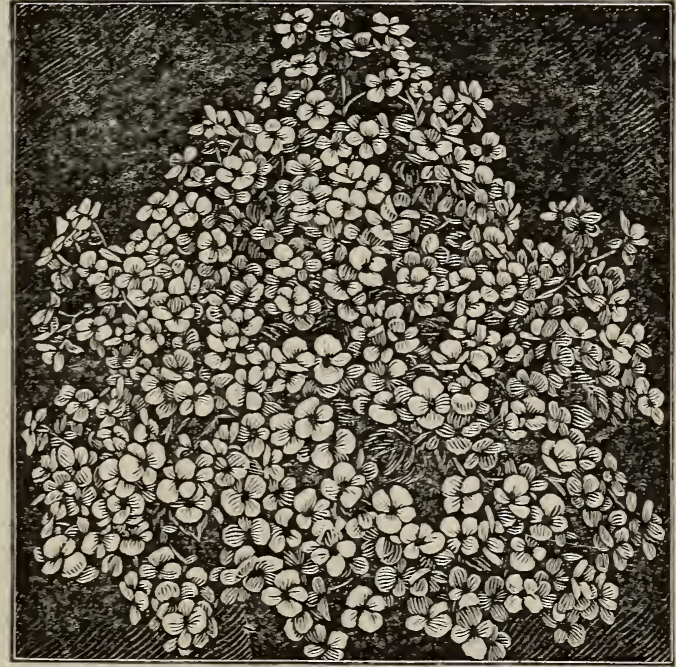

Gloire de Lorraine.

Ve also offer nice plants of this new sort, propagated from stock received direct from the originator in Scotland. Cale donia is the same in hibit, height, foliage and floriferousness as the Lorraine. The flowers however, ar pure white. In $3 \frac{1}{2}$ inch pots, $75 \mathrm{cts}$. each. In 6 inch pans, $\$ 2.00$ eacl.

ARECA LUTESCENS. (Ostrich Feather Palm.) A majestic palm. Its dark, glossygreen leaves are gracefully cirved on slender stems. The trunk and stems are golden yellow, iregularly spotted with bronzy green. In 3 pots, $\$ 2.00 ; 7$ inch pots, $\$ 3.00$ cach.

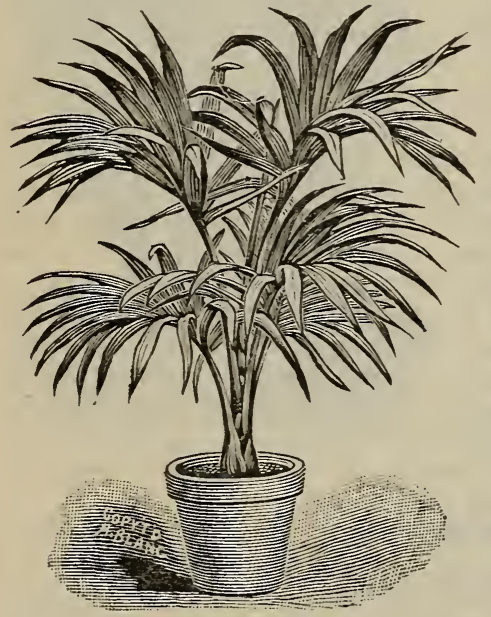

Kentia Belmoreana.

$\$ 1.00 ; 7$ inch pots, $\$ 1.50 ; S$ inch pots, $\$ 2.00$.

KENTIA BELMOREANA. (Curly Palm.) Recognized one of the best for all purposes, being able to withstand more illusage, perhaps, than any other. The foliage is dark glossy green, the segments wide and gracefully recurved. In 4 inch pot, $75 \mathrm{cts}$.; 5 inch pot, $\$ 1.00 ; 6$ inch pot, $\$ 1.75 ; 7$ inch pot, $\$ 3.50$ each.

cocos WEDDELLIANA. The most slender and graceful of the upright feather-leaved palms. The leaves are very finely formed, and of great beauty. In $2 \frac{1}{2}$ inch pots, $30 \mathrm{cts}$.; 3 inch pots, 50 cts.; $3 \frac{1}{2}$ inch pots, to cts. each.

LATANIA BORBONICA. (Fan PaIm.) This is a typical palm and is more largely used than any other. It is of strong, healthy habit, and especially suitable for window culture. In $3 \frac{1}{2}$ inch pots, 50 cts.; 4 inch pots, 70 cts.; 5 inch pots, \$1.00; 6 inch pots, $\$ 1.50$; 7 inch pots, $\$ 2.50$ each.

PANDANUS UTILIS. (Screw PaIm.) Very decorative and usefulfor the window garden. The large leaves in leaving the stem, form a continuous spiral. It is a native of the Hatvaiian Islands where the natives use its fibre for making cloth. In 4 inch pots, 50 cts.; 6 inch pots, $\$ 1.00 ; 7$ inch pots, $\$ 2.00$ each.

CYCAS REVOLUTA. (Sago Palm.) A faror. it for for Conservatory,
window Garden and piazza decoration. It is of very odd and beautiful growth. In 6 inch pots,

DRACENA INDIVISA. Valuable as a window plant, also for centres for baskets, vases, etc. $50 \mathrm{cts}$. to $\$ 1.50$ each.

DRACEVA TERMINALIS. A beautiful decorative plant, gorgeous shades of crimson, bronzy green, and pink foliage. $50 \mathrm{cts}$. to $\$ 1.50$ each.

ARAUCARIA EXCELSA. (Norfolk Island Pine.) The rich feathery, deep green branches of this charming conifer are arranged in whorls at regular distances on the stem. It is one of the most popular and beautiful foliage plants grown. In 5 inch pots, 2 tiers, \$1.00; 6 inch pots, 4 tiers, \$2.00 each.

ASPARAGUS SPRENGERI. The beautiful green feathery sprays, which drop gracefully, are often 3 to 4 feet in length. Excellent for hanging pots. $25 \mathrm{cts}$. to $\$ 1.00$ each.

RUBBER PLANTS. Ficus Elestica. We can furnısh nice, healthy plants of this favorite at from $\$ 1.00$ to $\$ 5.00$ each, according to size.

NEPHROLEPSIS EXALTATA BOSTONIENSIS. Boston Fern. A very popular window-plant. It bears well with heat, dust and neglect, and always has a bright, fresh appearance. Strong plants, $50 \mathrm{cts}$. to $\$ 2.00$ each.
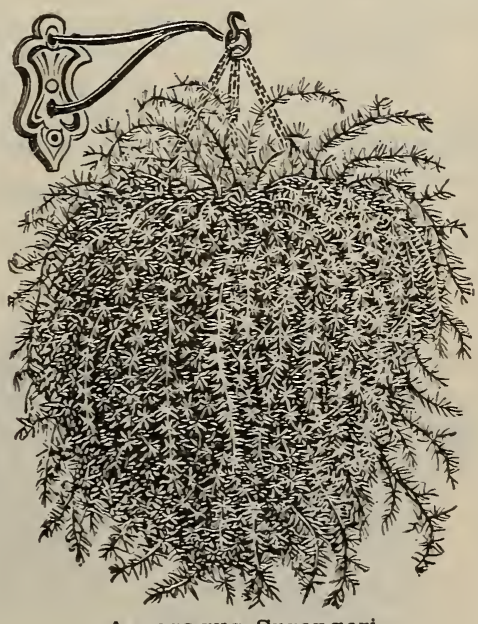

Asparagus Sprenger 


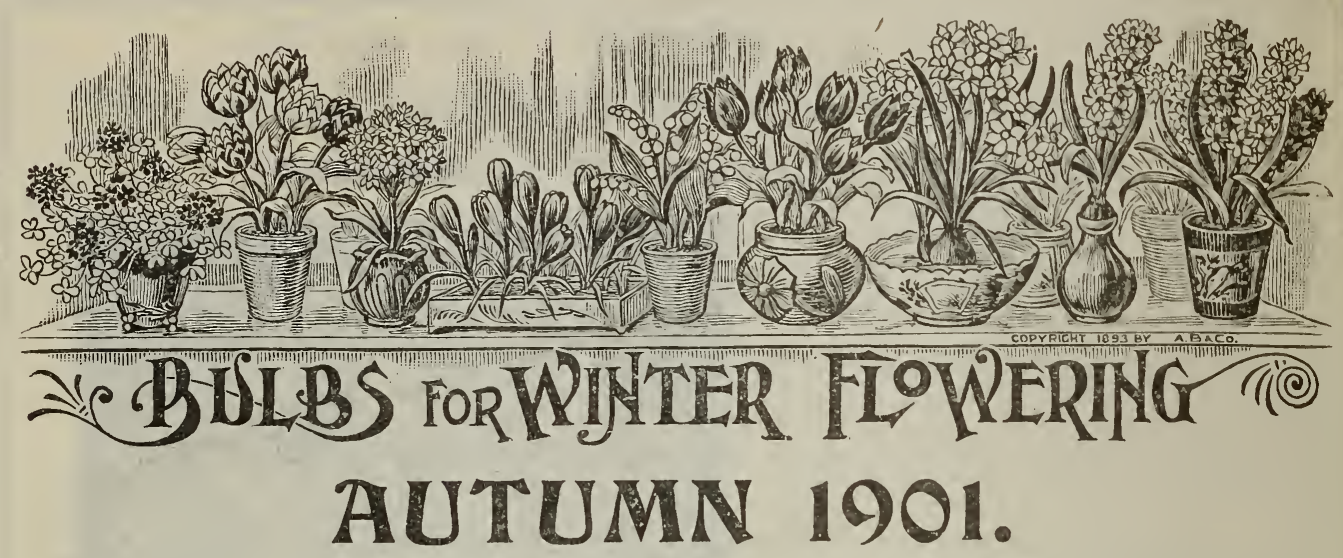

We thank our many customers and friends for their orders and recommendations.

We are glad to announce that the quality of the bulbs we offer this year is very superior, owing to the prevalence of favorable weather during the growing and ripening periods in the several countries from which we import them.

The prices have been carefully considered, and in niny instances reduced. Hence with these encouraging conditions we expect an increased denand. Our bulbs have been produced for us, under contract, by the same growers for a great many years and are the best obtaninable.

THE SOR'TS GROWN IN EUROPE HAVE BEEN SELECTEN PFRSONALIY BY OUR MR. ARCHIBALd SMITH. ThOSF FROM BERMUDA ARIS ALSO THE RLSUL'T OF OUR REP-, RESENTATIVI:'S VISIT TO THE ISLAND, WHILE OTR JAPANESF; SHIPAIENTS ARE IN ACCORDANCE WITH MR. BARR'S RLCOMMENDATIONS. THEREIORE WE, IIOPE TO THOROUGHLY SATISFY ALI, WHO FAVOR US WITH THEIR COMMANIS. WVE WRGE THE EARLY PIACING OF ORDERS.

Begin by planting a few Freesias, eight or ten bulbs in a six-incln pot or pan, in August, they will bloom before Christmas. Narcissus, Paper White Grandiflora and Hyacinths, White Roman can easily be flowered to decurate the Thanksgiving table, if planted in September. Lilium Harrisii potted in August slould produce its large, beautiful pure white, trumpet-sliaped flowers by Christmas. Dutch Hyacinths and Tulips ordinarily bloom in about four months from time of planting, aud there is a host of other equally desirable and easily grown bulbous plants worthy of attention.

Balbs intended for flowering in the house should he potted as soon as receiver, and placed in a cool cellar or out-house; a succession of flowers will be obtained by bringing them, as wanted, into a room where the temperature arerages $70^{\circ}$ during the day and about $50^{\circ}$ at night. For out doors, the sooner after the beginning of October that bulbs intended for spring flowering out doors are planted, the finer will be the flowers, because they make some root growth before severe weather hegins, and thus obtain food from the soil instead of subsisting on themselves.

NOTICE. While we exercise the greatest care to have all Seeds, Plants, Bulbs, and Nursery Stock of the best kind, we do not give and our agents and employees are forbidden to give, any warranty, express or implied. If you do not accept the goods on these terms, you must return them at once, and all payments therefor will be refunded.

\section{JOSERH BRECK \& SONS} (Corporation.)

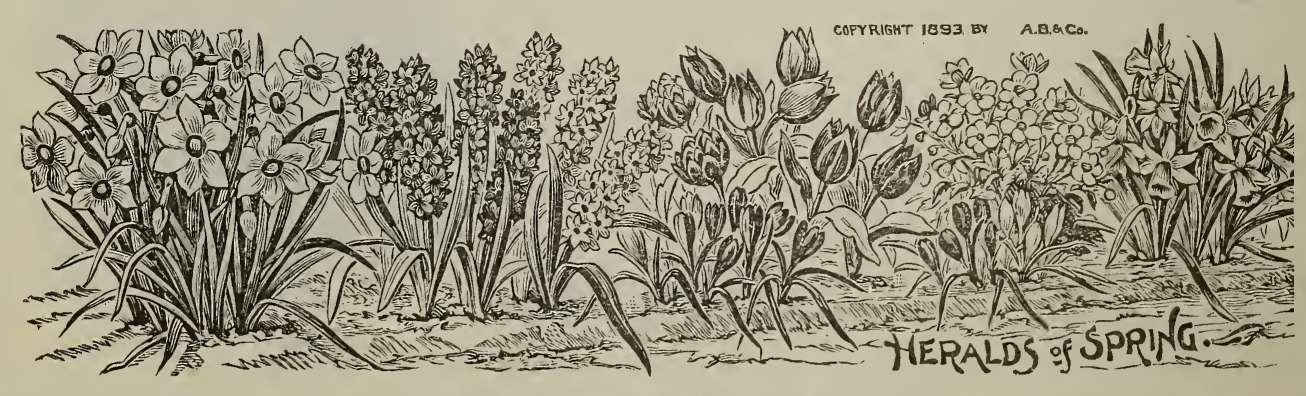




\section{MYACINTHS.}

The Hyacinth is the most popular, beautiful and fragrant of Holland bulbs. It is of almost every imaginable shade of color, and is suitable alike for house or

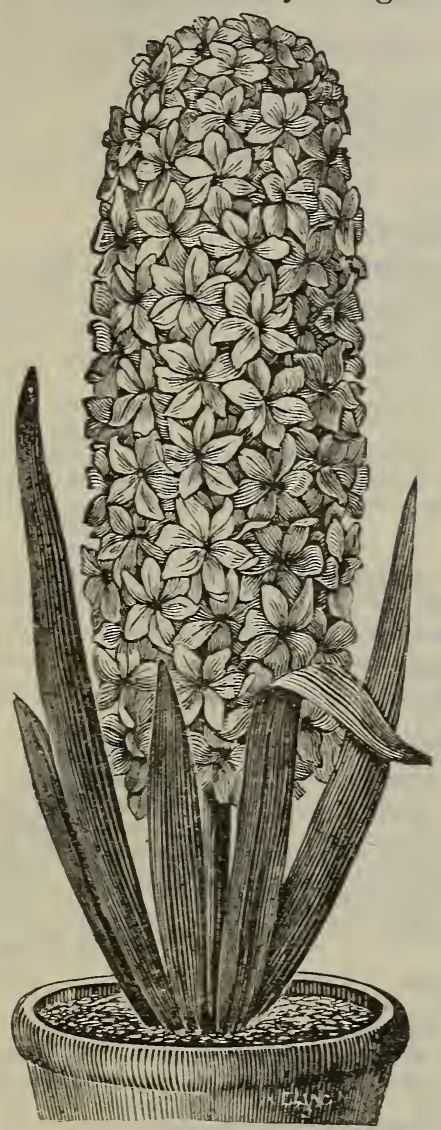

Single Hyacinth. garden culture.

Pot Culture. Plantings may be made at any time from September to December, though October is the best time. A light, rich soil with a mixture of well rotted cow manure, sand and leaf mould is most suitable, use a fire-inch pot and hare the top of the bulb just abore the surface of the soil. After setting the bulb, thoroughly firm the soil and give a good watering. The pots should then be set away in a cool cellar or out-house and covered over with coal ashes or some litter, for a few weeks, until the roots begin to grow; they may then be brought as wanted for a succession of flowers into a moderately warm light room.

Culture in Glasses. When it is desired to grow Hyacinths in water, they should be placed so that the base of the bulb merely touches the water. The glasses should then be set in a cool, dark closet, or in the cellar, until nearly filled with roots, when they may be brought into the light. Change the water frequently. Give as much fresh air as possible without letting the plants stand in a draught. It is of importance in growing Hyacinths in the parlor, that the atmosphere in which the plants are growing be kept moist, and as nearly as possible at a temperature of from sixty-five to seventy degrees.

Outdoor Culture. The bulbs may be planted any time after the beginning of October and before the winter frosts set in. Any good, well drained garden soil will answer. Dig deep, and mix in a little decomposed manure; set the bulbs from three to four inches below the surface, and about six inches apart; after the ground becomes frozen, gire a good covering of stable litter. In spring, about two weeks after the flowers have faded, the bulbs may be lifted, cleaned, packed in a box of dry sand and stored away in a cool place until wanted again for planting in the fall.

\section{NAMED HYACINTHS. BRECK'S HAND PICKED BULBS.}

Are all of flowering age, thoroughly matured and the finest varieties in cultiration.

\section{WE INVITE COMPARISON.}

Note.-As the single Hyacinths give the most satisfactory results, we always send a larger proportion of single than double, unless specially ordered to the contrary.

Price for our selection of single and double sorts, all colors, splendid varieties, $\$ 1.50$ per doz.

\section{Single Red, Rose and Pink.}

\section{DARK SHADES.}

Fiancee Royal. Very dark rose

Gertrude. Bright red, superb truss

General Pelissier. Dark crimson, very fine

Mr. Stanley. Deep red, beautiful truss

Mrs. Beecher Stowe. Dark rosy pink, large truss

Queen of Hyacinths. Brilliant vermilion, tine

Robert Steiger. Bright crimson, large

\begin{tabular}{r|} 
Each. \\
$\$ 0.0 S$ \\
.10 \\
.10 \\
.10 \\
$: 12$ \\
.12 \\
$.0 S$ \\
.05
\end{tabular}

LIGHT SHADES.

Cosmos. Deep rose, large bells

Fabiola. Beautitul soft rose

Giant of Roses. Splendid rose

Gigantea. Rose and blush, extra large bells

Lord Macaulay. Rose, shaded carmine

Madame Hodson. Beautiful pink, fine truss

Norma. Satiny pink, beautiful spike, large bells

Rubra Maxima. Deep pink, compact truss . Sultan's Favorite. Delicate rose, large spike

Each.
$\$ 0.0 S$
.10
.15
.10
.10
.05
.10
.12
.10




\section{HYACINTHS.- Single White, and White Tinted.}

\section{PURE WHITE. Each.}

Alba Superbissima. Pure white, fine spike \$o.12 Baroness Van Thuyll. Snow white, com.

pact truss
Blanchard. Dead white, large bells, early Urand Vedette. Pure white, large bells and truss

La Belle Blanchisseuse. Snowy white, excellent

Md. Van der Hoop. Waxy white, fine spike Paix de l'Europe. Pure white, splendid spike Queen Victoria. Clear white, fine truss
WHITE TINTED.

Elfrida. Creamy white fine truss

.10 Grandeur a Merveille. Beautiful blush, fine truss

La Franchise. French white, very large, fine truss.

L.rd Grey. White, slightly shaded, extra

Mammoth. Cream white, extra large bells

Seraphine. Blush white, slightly shot with rose

Voltaire. Creamy white, fine spike
Cleopatra. White, slightly tinted

Each.

$\$ 0.12$

.12

.15

.10

.12

.12

.10

.10

\section{Single Blue, Purple and Violet.}

\section{LIGHT SHADES.}

Blondin. Iight blue, extra truss.

DARK SHADES.

Each.

Baron Van Thuyll. Violet blue, large . \$0.08

Bleu Mourant. Rich blue ${ }^{\circ}$. I0

.12 Chas. Dickens. Dark blue, shading to light .os

. Ko King of Blues. Rich dark blue, extra

.10 Marie. Bright blue and purple, ex. fine

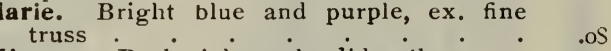

Mimosa. Dark violet, splendid spike : $\quad . \quad$.

.oS Willam I. Black purple, extra large . $\quad$.

.10 Uncle Tom. Dark violet, white eye . . .10

\section{Single Yellow.}

\section{LIGHT SHADES.}

Each.

o. 5

.10

Alida Jacoba. Bright canary, compact truss Heroine. Bright citron

Ida. Splendid yellow, fine spike

La Citroniere. Pale citron, close spike

La Pluie d'Or. Pale yellow

.12

.IO Solfateere. Orange yellow, extra fine.
Each.

$\$ 0.10$

.12

.10

.15
Duc de Malakoff. Orange, shaded red

King of Holland. Rich orange, fine truss

Prince of Orange. Dark yellow

\section{Double Red, Rose and Pink.}

The double varieties marked with an asterisk $(*)$ are the best for early forcing. LIGHT SHADES.

* Bouquet Royal. Light rose, dark eye

* Comtesse de Ia Cosie. Bright rose

* Czar Nicholas. Fine clear rose, large bells

* Grootvoorst. Creamy blush, fine truss

Le Grand Concurrent. Rose, dark centre

* Lord Wellington. Pale pink, large bells .

$$
\begin{array}{r}
\text { Each. } \\
\$ 0.10 \\
.12 \\
.10 \\
.10 \\
.12
\end{array}
$$$$
.10
$$

DARK SHADES.

Acteur. Very dark rose, large bells

* Bouquet Tendre. Brilliant dark red

Princess Louise. Deep carmine, very double

Debbitz. Brilliant scarlet.

* Noble I ar Merite. Deep rich rose, large spike

* Regina Victoria. Light red

Each

$\$ 0.12$

.08

.10

.12

$.0 \mathrm{~S}$

.08

\section{Double White, and White Tinted.}

\section{PURE WHITE.}

Blanchard Clear white, early

* Grand Vainqueur. Pure snow white

La Deesse. White, fine bells

La Tour d'Auvergne. Waxy white, large truss

* Prince of Waterloo. Albaster white

Sceptre d'Or. Pure white, fine large truss

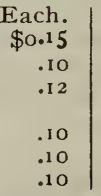

WHITE TINTED.

Each.

* Anna Maria. Blush white, violet eye. \$0.10

Buqquet Royal. Pure white, dark centre

* Grootvoorst. Pearl white, with lemon eye

La Virginite. Pale blush, fine spike

Md. de Stael Blush white, tinted eye .10 Non Plus Uitra. Creamy white, purple

\section{Double Blue, Purple and Violet.}

\section{LIGHT SHADES.}

* Blocksberg. Clear porcelain fine truss

* Garrick. Dark lavender, fine truss

* Md. Marmont. Iight blue, large bells

Pasquin. Porcelain blue, fine form

Rembrandt. Light lilac, with dark eye

Richard Steele. Clear blue, fine truss

\section{LIGHT SHADES.}

* Gœthe. Sulphur yellow

Heroine. Pure yellow

William III. Citron yellow, red centre

\section{Early Roman Hyacinths.}

\section{Double Yellow.}

Bride of Lammermoor. Dark purple, fine .10

Mignon de Dryfhout. Dark violet

* Prince of Saxe Weimar. Rich violet, fine

Robert Burns. Rich blue, fine bells.

\section{Each.}

DARK SHADES.

Each.

.10
.12

.08

.12

.10

This variety of the Hyacinth, a great favorite with all florists, may be had in flower by Christmas, when their fragrant flowers are most valuable for bouquets. They show to better advantage if four to six bulbs are planted in a pot.

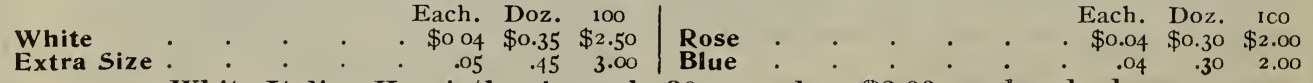
White Italian Hyacinths, 4c. each, 30c. per doz., \$2.00 per hundred.

Pink Italian Hyacinths, 4c. each, 30c. per doz., \$2.00 per hundred. 


\section{Miniature Hyacinths for Jardinets, Fancy Pots, Etc.}

These are similar to the ordinary Hyacinths, but diminutive, and are usually grown in sand or moss, like Crocuses; they look very nice when grown three or fcur together in pots.

Dark Red, Rose and Pink, Dark Blue, Light Blue .

Each Doz. 100

Mixed Colors

Collections of Hyacinths.

When ordering, please state if wanted for cultivation in pots or glasses:

No. I. 12 distinct named Hyacinths for pots $\$$ r.00 No.3. 25 distinct named Hyacinths for pots $\$ 2.00$

2. 12 distinct named Hyacinths for glasses $1.25 \mid \cdots 4.25$ distinct named Hyacinths for glasses 2.50

\section{CHOHCE UNNAMED MYACINTMS.}

Though without names, these are sound flowering bulbs of desirable varieties that attain about an equal height and bloom at the same time. They are likely to flower satisfactorily in either pots or beds and should not be confounded with the cheap mixtures frequently offered.

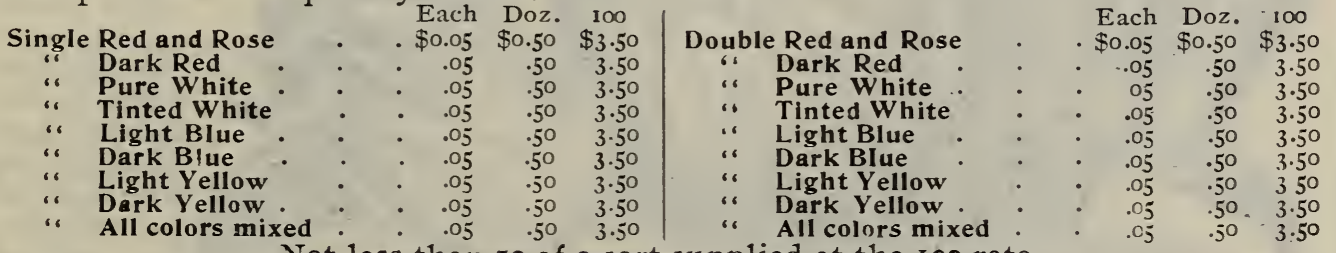

Not less than 50 of a sort supplied at the 100 rate.

Hyacinthus (Muscari).

(GRAPE, MUSK, AND FEATHER HYACINTHS.)

A group of hardy plants suitable for growing in pots, borders, rockeries, etc., valuable for cutting in spring.

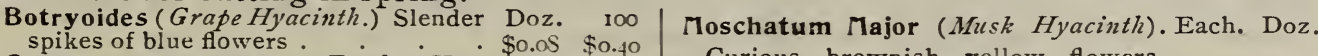

Comosum Monstrosum (Feather Hya.

cinth). Pretty plumes of light purple

flowers. A very remarkable and

charming sort; ought to be more

largely grown

Toschatum Major (Musk Hyacinth).
Curious brownish yellow flowers, strongly musk-scented; a pot of these will scent a whole house; it is hardy and easily grown

$\$ 0.15 \$ 1.00$

\section{Hyacinthus Candicans.}

A perfectly hardy, elegant border plant that grows to a height of four feet. The pure white, drooping flowers are borne on a central stem and are produced in July and August. Strong roots, each, 4 cts.; per doz., 35 cts.

\section{A GLORIOUS BED OF TULIPS.}

Design A.-A glorious effect is had by following either of the arrangements here indicated, viz.: (I) an I8-ft. Star Bed. (2) a I 2-ft. Star Bed. (3) a I 2 -ft. Circular Bed. Set the bulbs $3 \frac{1}{2}$ inches deep and 6 inches apart, each way.

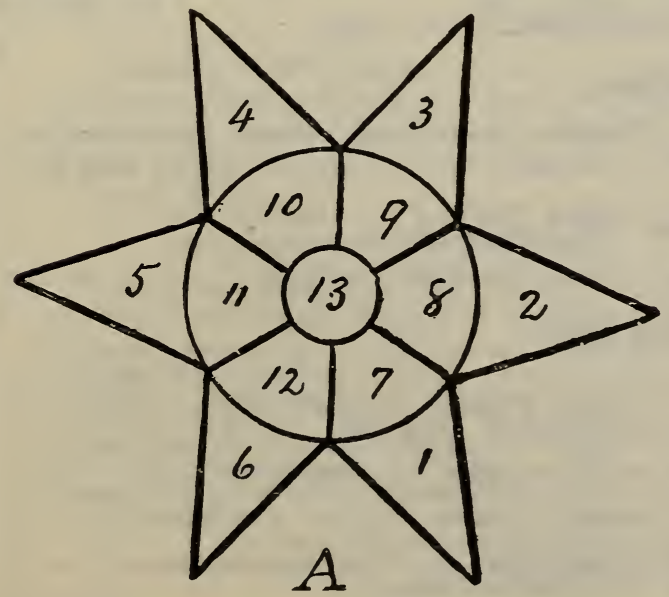

\begin{tabular}{|c|c|c|c|c|c|}
\hline No. & & & & Style I. & Style 2 \\
\hline I & Yellow Prince & • & . & 40 & 21 \\
\hline 2 & Perle Blanche & . & • & 40 & 21 \\
\hline 3 & Crimson King & . & . & 40 & 21 \\
\hline 4 & Cerise Grisdelir & . & . & 40 & 21 \\
\hline 5 & Queen Victoria & . & . & 40 & $2 \mathrm{I}$ \\
\hline 6 & Cottage Maid & - . & . & 40 & 21 \\
\hline 7 & Rosa Mundi. & - . & . & 38 & 15 \\
\hline$\$$ & Paul Moreel e & . & & $3 s$ & 15 \\
\hline 9 & Canary Bird & . & . & $3 s$ & 15 \\
\hline 10 & Proserpine. & & & $3^{S}$ & 15 \\
\hline $1 \mathrm{I}$ & Pottebakker (y & ellow & & $3 s$ & 15 \\
\hline 12 & Vermillion Bril & liant & . & 38 & 15 \\
\hline 13 & Kaisers Kroon & .. & . & 12 & 10 \\
\hline & Total & . & - & ${ }_{4} \mathrm{So}$ & 256 \\
\hline & Price & . & . & 6.25 & $\$ 2.5_{5}$ \\
\hline
\end{tabular}

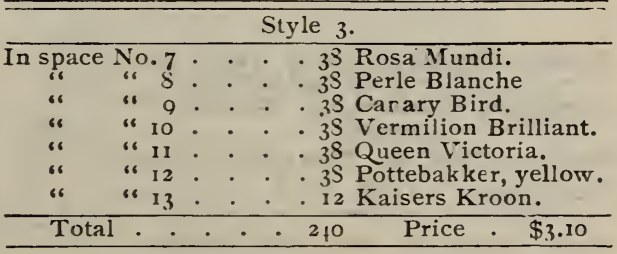




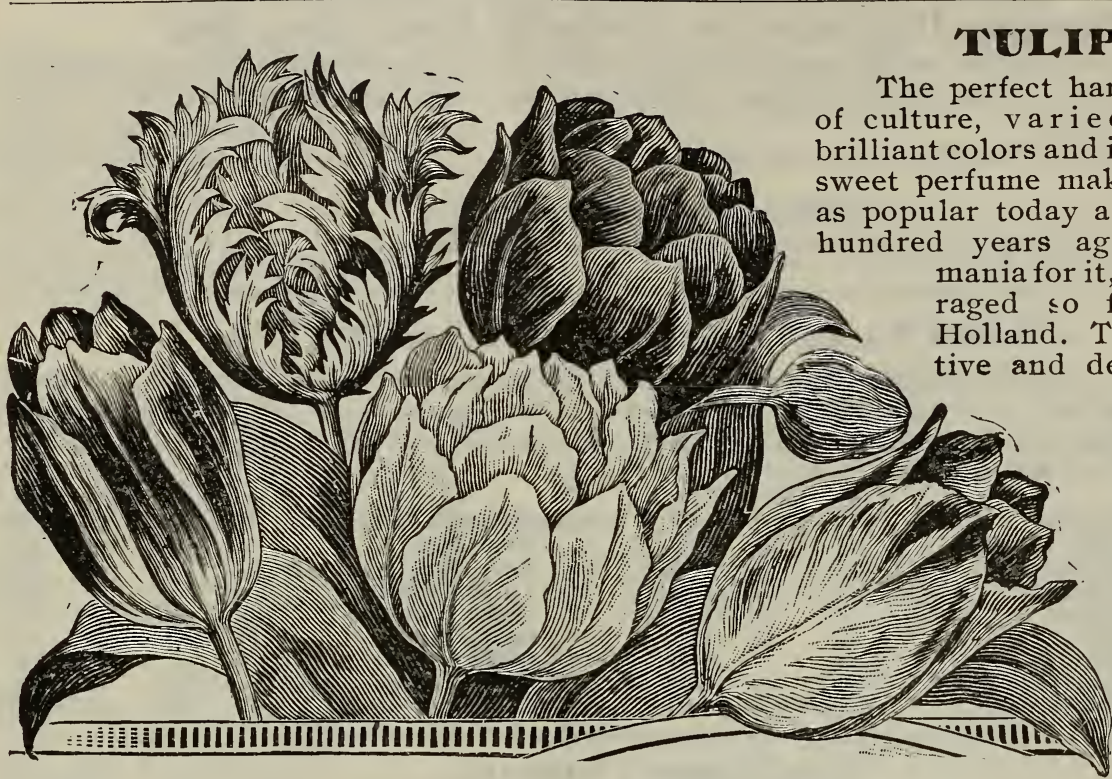

\section{TULIPS.}

The perfect hardiness, ease of culture, varied markings, brilliant colors and in some cases make the Tulip as popular today as it was two hundred years ago when the ynia for it, at any price, furiously in Holland. They are effective and desirable even às $\operatorname{sing} 1 \mathrm{e}$ specimens, but it is when grown in $\mathrm{m}$ asses that the best effect is produced. Any good garden soil will do for the Tulip. When naturally poor a mixture of equal parts well rotted manure, well rotted sods or good loam or leaf mould may be applied. See that the drainage is good before planting, which should be done in October or November. Set the bulbs three and a half inches deep and five inches apart. A half inch of sand beneath the bulb is of essential benefit in preventing injury from excessive wet.

VAN THOL TULIPS are the earliest and especially adapted for pot culture. The best effect is obtained by planting from six to twelve bulbs in a large pot.

The varieties marked ( $\dagger$ ) bloom simultaneously about twelve days later than the VAN THOLS. This key will be useful in selecting for masses. Although nearly all the single early sorts will force to a certain extent, those marked $\left({ }^{*}\right)$ are the most suitable. The kinds that have an (Ex:) affixed are the finest for exhibition. The figures affixed indicate about the height in inches to which each variety grows.

\section{Single Early - White.}

Alba Regalis, †9. White, large and fine $\begin{array}{cc}\text { Doz. } & \text { I00 } \\ \$ 0.90 & \$ 0.90\end{array}$

Duc Van Thol, *6. Pure white, very

Jant Van Delft, *8. Pure white: $\quad .20 \quad 1.25$

Jagt Van Deift, *8. Pure white. $V_{i c}{ }^{115} \quad$ I.00

toria). White, tinged with rose; ex-

cellent bedding sort

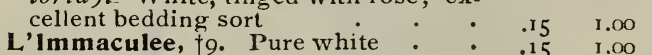

Perle Blanche, $\uparrow$. Pure white

Doz. 100

Pottebakter $\$$ \$o.20 \$1.25 splendid large and showy flower. White Hawk, t10. Pure white, unsurpassed either for forcing or beds

White Swin, 10. White, egg shaped flowers, late.

Pax Alba, *6. Pure white

$\begin{array}{ll}.25 & 1.50 \\ .30 & 2.25 \\ .25 & 1.50 \\ .15 & 1.00\end{array}$

\section{Yellow.}

Canary Bird, *8. Clear, rich yellow; Doz. \begin{tabular}{cc|cc} 
Doz. & I & Thomas Moore, ${ }^{*}$ Io. Orange, very
\end{tabular} Chrysolora, Ex:*9. Pure yellow; large flower; extra * ' Early, very fine . Pottebakker, *8. Clear yellow, large flower.

$\begin{array}{ll}.15 & 1.00 \\ .25 & 1.50 \\ .25 & 1.75\end{array}$
distinct

Yellow Prince, $f^{*} 7$. (Synonym; La Pluied'Or). Bright yellow, large an l showy, excellent for bedding . $\quad . \quad \begin{array}{lll}.20 & 1.25\end{array}$

\section{Red and Rose}

Couleur Cardinal, Ex:9, Rich, dark red, bold flower, distinct and fine

Cramoisie Pourpre, $\uparrow 7$. B e a $t$ if $\mathrm{i}$ shade of rosy purple.

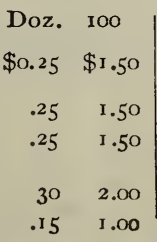

Rachel Ruisch, to. Bright Rose

Doz. $\quad 100$

Duc Van Thol, *6. Pale rose, very fine

Proserpine, Ex: $† * 8$. Rich, dark rose, splendid, large flower; very effective.

Rosa Mundi, $\nmid 8$. Rich rose, shaded. Rosamundi Huikman, t9. Silvery Rose Grisdelin, * Delicate rose and

$\$ 0.15 \$ 1.00$

$.15 \quad 1.00$

$.25 \quad 1.50$

Rouge Luisante, Ex: $\dagger^{*} 7$. Fine deep rose, splendid, large flowers $\quad .55 \quad 4.00$ Van Goijen. tio. Light rose, fine for
forcing and bedding 


\section{SINGLE EARLY TULIPS.-Continued.}

\section{Scarlet and Crimson.}

Artus, †7. Scarlet, fine bold flower

Bacchus, to. Crimson scarlet

Belle Alliance, Ex:* (Synonym: Waterloo). Brilliant scarlet, extra.

Brutus, *6 Bright orange crimson, very

crimson King, $\dagger \dot{7}$. Scarlet crimson, very showy

$\begin{array}{|cc|}\text { Doz. } & 100 \\ \$ 0.12 & \$ 0.75 \\ .15 & 1.00 \\ .20 & 1.25 \\ .15 & 1.00 \\ .12 & .75\end{array}$

\section{Purple and Violet.}

Duc Van Thol, *6. Crimson

Duc Van Thol, *6. Scarlet

Paul Moreelse, $t S$. Cerise crimson:

Pcarlet, ex. • $\quad . \quad .20 \quad 1.25$

Stanley, to Splendid deep red . $\begin{array}{lll}.20 & 1.50\end{array}$

Vermillion Brilliant, Ex.: *S. True vermillion, extra fine for pots and massing
Potler, tS. (Syn. Paulus Potter). Reddish violet, very distinct

Queen of Violets, †*9. (Syn. President Lincoln.)
Doz. $100 \mid$ Van der Veer, $\dagger^{*} 6$. Purplish violet, $\$ 0.15 \$ 1.00$

large flower, distinct and fine

Wouverman, Ex:*5. Deep purple vio. let, splendid large flower $\begin{array}{rr}\text { Do7. } & 100 \\ \$ 0.15 & \$ 1.00 \\ .15 & 1.00 \\ .15 & 1.00 \\ .20 & 1.25 \\ .20 & 1.50 \\ & \\ .25 & 1.75\end{array}$

Doz. 100 $\$ 0.15 \$ 1.00$

$.15 \quad 1.00$

\section{Striped and Variously Marked.}

Cerise Grisdelin, Ex : †7. Purplish rose, margined with creamy white

Cottage Maid, $\dagger^{*} 6$. Rose pink, shaded white, very pretty

Duchess de Parma, *3. Orange red, muc Van Thol, *o. Red, margined with yellow

Duc Van Thol, *6. Gold striped, very fine

Fablola, Ex :*7. (Syn. Grand $\dot{D} u c$ de Russie.) Rosy purple and white, extra fine flower.

$\begin{array}{cc}\text { Doz. } & \text { Ico } \\ \$ 0.30 & \$ 2.00 \\ : 15 & 1.00 \\ .15 & 1.00 \\ .15 & 1.00 \\ .20 & 1.25 \\ .15 & 1.00\end{array}$

Globe de Rigaud, Ex: $\dagger^{*}$. Purplish slate and white, very large and fine Joost Van Vondel, Ex: $\dagger^{*} 9$. Rosy crimson, with a few white pencillings,

Kaizer's Kroon, Ex: $\dagger^{*} 9$. Crinison scarlet, margined with clear yellow Moliere, to. Purple, with yellow base Prince of A ustria, to. Rich orange red Royal Standard t7. (Syn. Standard Silver). White feathered with rot crimson

Royal Standard, Gold Striped, tr, Scarlet and yellow

Doz. 100 $\$ 0.20 \$ 1.25$

$.15 \quad 1.00$

$.20 \quad 1.25$

$.20 \quad 1.25$

$.30 \quad 2.25$

$.20 \quad 1.25$

$.30 \quad 2.25$

\section{Sweet Scented Tulips.}

There are only a few early varieties that have a sweet fragrance, the three following are the most desirable. Plant a few once and you will never again think your bulb planting complete without them. They are as suitable for pot culture as for bedding.

Mr. Gladstone. Beautiful clear canary-yellow, large cup-shaped flower, tea scented

\section{Unnamed Tulips.}

\section{SINGLE, EARLY, SEPARATE COLORS.}

These are first-class bulbs of popular varieties that shou'd grow to the same height and bloom together. They are especially suitable for beds, borders and massing where effective contrast is desired.

White Shades .

Pink Shades

Scarlet Shades

Yellow Shades

Deep Red.

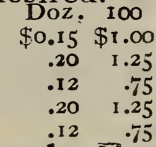

Singie Early
Red and Yellow

Crimson and White

Purple and White .

Variegated
Doz. 100 $\$ 3.15 \$ 1.00$ $.15 \quad 1.00$ $.15 \quad 1.00$ $.15 \quad 1.00$ . I 1 年 1.00

BRECK'S SPECIAL. This mixture embraces not only all colors, but the best sorts that grow to about an equal height and flower simultaneously; it is without a rival for variety and brilliancy. Per doz., $20 \mathrm{cts}$.; per I0O, $\$ \mathrm{I} .50$; per 1000, \$I 2.00 .

Single Early, first quality imported mixture. Per doz., I 2 cts.; per 100, 0.80 ; per $1000, \$ 7.50$.

\section{Single Late or Florist's Tulips.}

This very beautiful and interesting class flowers in May, considerably later than the other sections. They are of taller growth, and produce a gorgeous effect. \begin{tabular}{l|l|l} 
Bizarres, yellow ground, with crimson, Doz. I00 & $\begin{array}{c}\text { Darwin. The Dutch and English grow- } \\
\text { ers have forced this variety and had }\end{array}$
\end{tabular}

Breeders, mixed, very effective $15 \$ 1.00$ splendid blooms in the market during March. Its extra size and depth, and variety of color make it a great colors ple, lilac, or black markings

Roses, white ground, with scarlet, pink, or red markings

$\begin{array}{ll}.15 & 1.00 \\ .15 & 1.00\end{array}$

$.15 \quad 1.00$

Darwin. Ten splendid sorts, named

Fine Mixed, all colors 


\section{TULIPS.-Continued.}

\section{Parrot Tulips.}

This species has fringed flowers, brilliant crimson and yellow, with shades of bright green; very gay and effective in mixed borders, and forming a fine succession to the early flowering varieties.

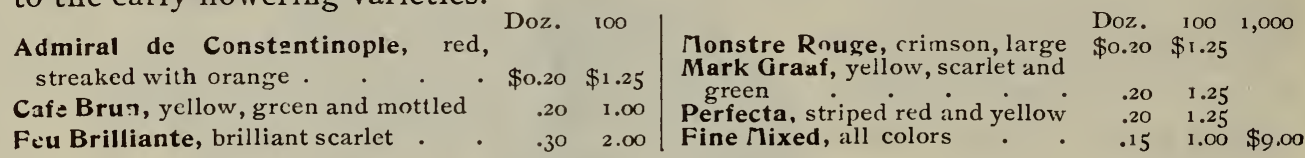

\section{Double Tulips.}

The earlier varieties of this beautiful class of Tulips are admirably adapted for forcing. The latter kinds are very effective for bedding, producing a dense mass of brilliant colors which remain in perfection a long time.

NOTE.-The words "early, medium and late," indicates the t:me of flowering of the different sorts.

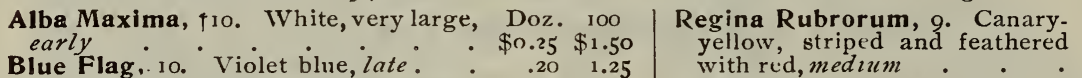

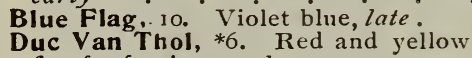

Duc Van Thol, *6. Red and yellow,

Duc Van Thol, *6. Dark red, early

Duke of York, Ex: *10. Dark rose,

Gloria Solis, +8 . Reddish-brown, with yellow edges, early

Imperator Rubrorum, Ex: $\nmid * \delta$. Scarlet crimson, very brilliant, early.

La Candeur, Ex: 8 . Pure white, erect habit, excellent for beds, medium

Murillo, Ex: *8 Pale rose and white, distinct and fine, medium

Princess Alexandra, ${ }^{*} 6$. Red margined yellow, erect and showy, early

Pæony Gold, 10. Golden yellow striped red, late

Prony Red, sо. Diep crimson, late:

Purple Crown, 10. Crimson maroon, early.

$$
\begin{aligned}
& .20 \quad 1.25 \\
& .15 \quad 1.00 \\
& .15 \quad 1.00 \\
& .20 \quad 1.25 \\
& .20 \quad 1.25 \\
& \text {.30 } 2.00 \\
& \text {.I5 } 1.00 \\
& .30 \quad 2 . \mathrm{CO} \\
& .35 \quad 2.25 \\
& .25 \quad 1.50 \\
& .20 \quad 1.25 \\
& 1.25
\end{aligned}
$$

$\begin{array}{rrrr}\text { Doz. } & 100 & 1,000 \\ \$ 0.35 & \$ 2.25 & \\ .25 & 1.50 & \\ .25 & 1.50 & \\ .30 & 1.75 & \\ .40 & 2.75 & \\ .25 & 1.50 & \\ .20 & 1.25 & \\ .20 & 1.00 & \$ 9.00 \\ .20 & 1.25 & 11.00\end{array}$

\section{Tulip Species.}

Each of the following are distinct species, blooming somewhat later than the single, early Tulips and therefore valuable for mixed borders. They are very distinct in habit, and have beautiful and intense colors. Excellent for cutting.

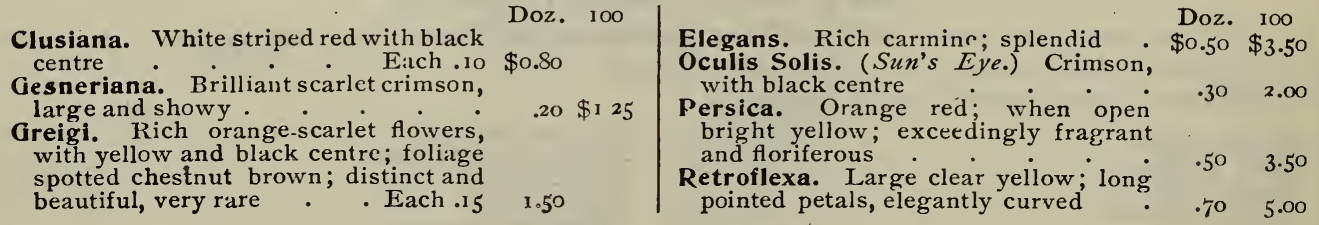

\section{NARCISSUS OR DAFFODILS.}

We have the most complete collection of Narcissus in America, and are in a position to cater to the wants of the public better than any house in the country.

Outdoor Culture. The Daffodil will grow in any ordinary garden soil and in almost any situation, but prefers moderately stiff, well-drained soil, in situations slightly shaded, such as the herbaceous border and the margins of flower-beds, along the outside edges of shrubberies, on woodland walks and on the margins of lakes and streams, or for naturalizing in the grass or woodland. Planting may be done in the fall any time before the frost sets in, October being the usual month for doing this. Once planted they should not be disturbed further than dividing and resetting in August once in three or four years, when they get too crowded. The varieties marked " $H$ " are hardy ; those marked " $H H$ " are hardy with a good covering of leaves or litter during winter; the kinds marked "' $T$ " are tender, and most suitable for growing indoors.

Pot Culture. It is unnecessary to say anything as to the merits of Narcissus of all kinds for this purpose, as their popularity is universal. At the head of the list 


\section{NARCISSUS. - Continued.}

stands the Tazetta, or Polyanthus Narcissus, with its large bunches of fragrant flowers. The Paper White Grandiflora and Double Roman Tazettas are very largely used for forcing. All the varieties of the group are suitable for this purpose, and most excellent for cut flowers. The Bulbocodium or Hoop Petticoat Daffodil, planted say 3 to I 2 in a pot, is most unique and attractive, and the same may be said of the Cernuus or Nodding Daffodil. The Campernelle or Large Jonguil ( $N$. Odorus), and the Single and Double SweetScented Jonquils are splendid - the last-mentioned being exquisitely perfumed. Triandrus, the little Cyclamen Flou'ered Narcissus, is a perfect gem, one of the choicest things we offer. The Moschatus and other Spanish Daffodils are also worthy of special mention. For culture, the hints given under hyacinths may be followed. One very important point is to keep them cool for the first four or five weeks when they are com-

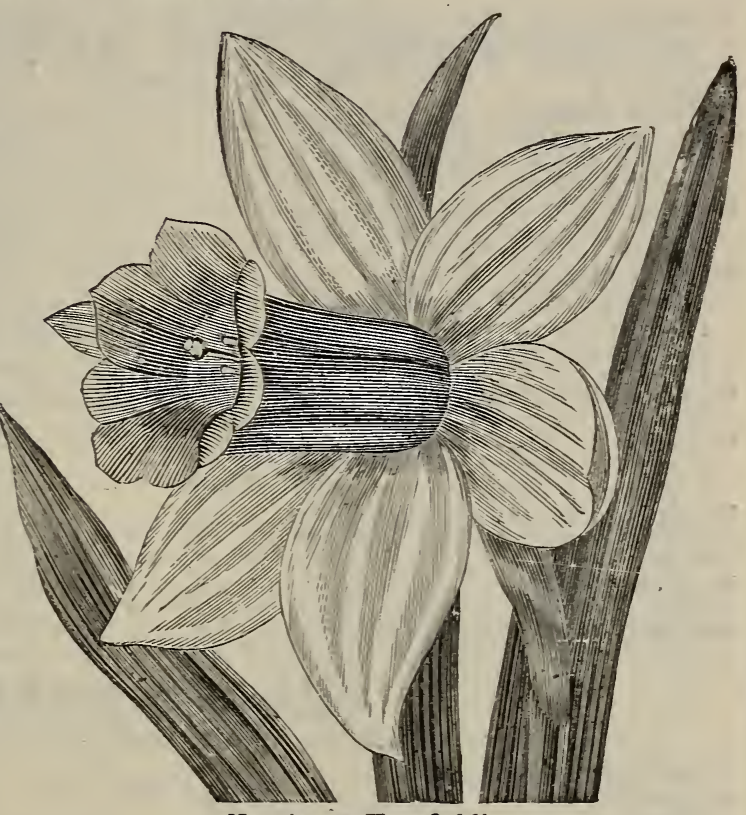

Narcissus Horsfleldi. mencing to grow. After the roots are grown and the tops well started, they may be pushed forward more quickly in heat. In cutting for sending to friends or for market, the flowers should be cut in the bud, and when placed in water they will open out beautifully.

Ard Righ, or Irish King. A mag-

Each Doz. Ioo

nific ent Daffodil; pure yellow,

with the perianth el-gantly twisted,

and the trumpet widely reflexed and

fringed. $\mathrm{H}$.

Bic olor. Golden yellow trumpet with white perianth; ten days later than Horsfieldi. H

Bicolor Emperor. Very 1 a rge;
trumpet golden yellow, perianth trumpet golden yellow, perianth

Bicolor Empress. Immense golden yellow trumpet, with a broad white perianth of great substance. H .

Bicolor Grandis. Color same as
Horsfieldi, but a larger and later flower H Horsfieldi (King of Daffo-

Bicolor Horsfieldi ( King of Daffo-
dils). Large and stately; trumpet golden yellow, perianth white. H .04 $\quad .35 \quad 2.50$

Biflorus (Primrose Peerless). Pure white perianth, with soft yellow crown; two flowers on each scape;

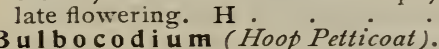

B $\mathbf{l}$ b o c o d i u m (Hoop Petticoat)
Rich yellow, small flower. IH

Bulbocodium Citrinus. Pure sul. phur-yellow; large, distinct, and besutiful. $\mathrm{HH}$

Bulbocodium Monophyllus (White Hoop Petticoat). Pure white; in bloom at Christmas. HH

Cernuus (Nodding W7ite Daffodil).
Trumpet and perianth clear silvery white. HH . • •

Countess of Annesley. One of the best; trumpet rich yellow, perianth sulphur; large and early. $\mathrm{H}$.

GoIden Spur. Rich, deep yellow; early and very large. H
Hume's White. Perianth sulphurywhite, trumpet yellow, distinct and fine. $H$.

In com pa rabilis (Peerless Narcissus). Large Primrose perianth, sulphur crown. H

Incomparabilis Cynosure. Divisions creamy white, cup yellow; very distinct. $\mathrm{H}$

Incomparabilis Sir Watkin (The Big Welshman). Very large and beautitul; the tube is of a rich golden yellow, the perianth pale primrose. H.

Incomparabilis Stella. Pure white, with a yellow crown; excellent for forcing. $\mathrm{H}$

Each Doz. 100

Jonquilia, Sweet $=$ Scented Single Jonquil. Deep yellow, very frag. rant; valuable for pot culture. $\mathrm{HH}$

Leedsi A mabilis. Perianth white; cup very long, changing from primrose to white. H $\mathrm{H}$.

Leedsi Circe. Divisions white; cup canary-yellow, changing to white.

Moschatus (True.) An exquisite dwarf, pure white variety

Nanus. Yellow, very dwarf, beautifully plaited trumpet. The height of this sort is about four inches, which makes it valuable for edging. $\mathrm{H}$

Nelsoni Major. Long, golden yellow tube, and pure white perianth. H

Odorus, Campernelle J on quil (Fragrant Narcissus). Large, clear yellnw flowers, with well opened and recurved crown; two or three flowers borne on each scape. HH

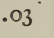




\section{NARCISSUS. - Continued.}

Obvallaris (The True Tenby Daf. Each. Doz. 100 fodil). Bright yellow, dwarf and floriferous, one of the earliest to bloom. H

Pallidus Pracox. The finest of the pale sulphur trumpet sorts; perianth nearly white; very early flowering. $\mathrm{HH}$

Poeticus (The Pheasant's Eye, or Poet's Narcissus). Pure white $\begin{array}{llll}\text { with red crown; very fragrant. H } & .02 & .15 & .75\end{array}$

Poeticus Ornatus. Blooms a month earlier than the common Poeticus. The flowers are beautifully rounded and large, perianth pure white with a red cup. $H$.

Poeticus Radiiflorus. Pure white with dark red crown. H

Princeps. Large yellow trumpet, flowering, desirable variety. H

Pseudo=Narcissus (The Lent Lily.) Rich yellow trumpet, perianth white. $\mathbf{H}$

Rugilobus. Quite like Emperor, but earlier and not so large. H Scoticus. Perianth white, trumpet yel.
low, full and elegantly serrated. $\mathrm{H}$.
Spurius Coronat us (Gordon) Each. Doz. 100 Light yellow; remarkable for its broad expanded trumpet and spreading perianth. H $\mathrm{H}$ primen

T riand rus Albus and interesting species, producing three to six flowers on a stem; the cup is pale sulphur when first open. ing, ultimately changing to white: the divisions are long and reflexed like a Cyclamen, creamy white and very oraceful.

Trumpet Major. Deep golden. yellow color; one of the best for $\begin{array}{lllll}\text { garden culture and forcing. } \mathrm{H} & . & .03 & .25 & 1.50\end{array}$

Trumpet Maximus (The Great Trumpet Daffodil). Very large and fine; trumpet and perianth deep golden yellow; trumpet well npened, recurved and fringed; perianth slightly twisted. $\mathbf{H}$.

Trumpet Minor. Elegantly tivisted petals, trumpet a little deeper yellow; a very distinct variety. $\begin{array}{lllll}\mathbf{H} & .03 & .20 & 1.50\end{array}$

Mixed Narcissus from many choice sorts. $\mathrm{H}$

$.03 \quad .30 \$ 2.00$

\section{DOUBLE DAFEDILS.}

The hardy varieties are unsurpassed for massing in quantity, and all the sorts may be grown in pots.

Aurantius Plenus (Eggs and Bacon), Doz. 100 (Orange Phanix). Soft sulphur with crim. son center, very double; showy and dis tinct. $H$.

Cernuus Plenus (The Swan's Neck Daffo. dil). An extremely beautiful variety, bearing full double flowers of a delicate creamy white, sometimes tinged with lemon in the center. $\mathrm{HH}$.

Incomparabllis Plenus (Butter and Eggs). Yellow, very double. H.

Jonqullla Plenus (The True Double SweetScented Jonquil). Heads of small very double flowers, of a deep, golden yellow, and powerfully fragrant. $\mathrm{HH}$.

Poeticus Plenus (Double White Poet's Nar. cissus). Pure white, like a Gardenia, very double and fragrant. $H$.

Rip Van Winkle (The Irish form of $\dot{N}$. Minor Fl. Pl.) Pale, rich yellow, shaded, full double, curiously pointed and fringed. The flower is small and perfect, just the size for a buttonhole bouquet. Must be grown in light, gritty snil. HH. Each, .10

Sulphureus Nanus (Codlins and Cream) (Sulphur Phonix). The largest of all the double daftodils; flowers, creamy white, changing to pure white, and of great sub. stance. H. . Each, 15

Telamonius Plenus (Double Daffodil), (Von Zion). Large, double, deep golden yellow ffowers. $\mathbf{H}$.

$$
\text { \$า } 25 \$ 1.50
$$

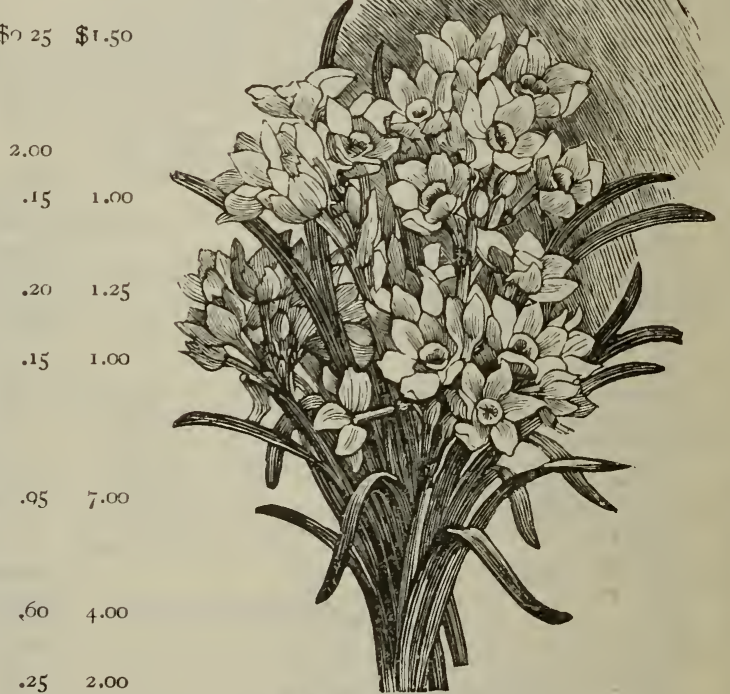

Narcissus Paper White Grandiflora.

\section{Polyanthus Narcissus (N. Tazetta).}

The varieties of this group produce an abundance of large trusses of very sweetscented flowers, varying in coler from pure white to deep golden yellow; easily cultivated and excellent for pots and forcing. The Paper White Grndiflora and Double White Roman can be forced into bloom by Christmas.

Early Double Roman. White, with Doz. 100 I000|Grand Primo. White, citron cup, Doz. 100 orange nectary. T. .

Paper White Grandiflora. An im.

proved form of Paper White, being

larger and earlier than the old sort.

T. . . . . . . . $\quad . .25 \quad 1.50 \quad 12.00$

Gloriosa. White, yellow nectary. T. $.25 \quad 1.50$

Grand Monarque. White, citron

nectary. •

\begin{tabular}{|c|c|c|}
\hline 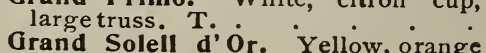 & .25 & $\$ 1.50$ \\
\hline $\begin{array}{l}\text { cup. T. } \\
\text { States General. Creamy white, yel. }\end{array}$ & .25 & 1.50 \\
\hline & .25 & 1.25 \\
\hline Fine Mixed White $\mathrm{V}$ & $\begin{array}{r}.45 \\
.20\end{array}$ & $\begin{array}{l}3.00 \\
1.25\end{array}$ \\
\hline ine Mixed & .20 & 1.25 \\
\hline
\end{tabular}




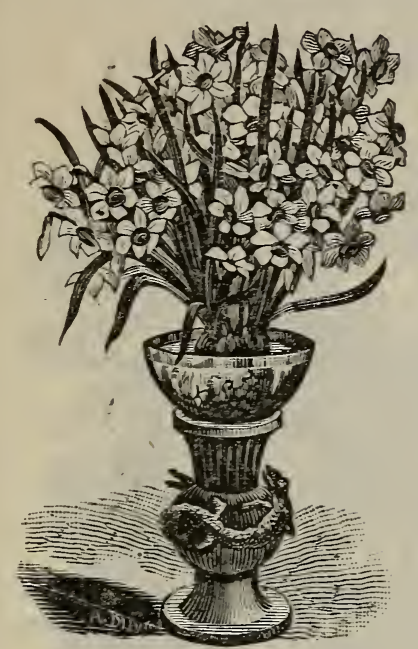

Chinese New Year's Lily.

\section{CHINESE NEW YEAR'S LILY.}

(NARCISSUS ORIENTALIS).

No care whatever is required in the cultivation of this beautiful and interesting bulbous plant. Use shallow dishes about three inches deep, into which put about one inch of gravel. Set the bulbs on this and fill in with small stones or pieces of marble to keep them upright, and keep the dish full of water. These bulbs do not require to be put in the dark, but a little shading until the leaves begin to grow is beneficial. A pinch of wood ashes now and again, and when changing the water putting a few drops of ammonia into it will largely ensure success. ro cts. each; $\$ 1.00$ per doz.

\section{LILIES.}

Everything considered, there is no class of hardy flowering plants so desirable as the Lily family. Their cultivation is not difficult, nearly all of the varieties being hardy and flourishing in ordinary garden soil. We recommend deep planting, from six to twelve inches, according to the size of the bulb and depth of soil. When it is practicable to obtain peat, or leaf mould and sand in which to grow them, better results will follow.

Following are the usual dates at which we make delivery of the different varieties of Lilies.

Harrisii, July I5; Longiflorum (Bermuda grown), Candidum, Aug. Io; Tenuifolium, Wallacei, Pardalinum, Dalmaticum, Chalcedonicum, Canadense, Sept. ro; Auratums, Speciosums, Testaceum, Davuricums, Elegans, Atrosanguineum, Philadelphicum, Browni, Croceum, Martagon, Oct. I ; Concolor, Krameri, Parryi, Batemanice, Hansoni, Humbolti, Leichtlinii, Monadelphum, Nov. I.

Pot Culture. The best compost to use is loam and peat in about equal parts, with the addition of a sprinkling of sharp sand and powdered charcoal. Select a large-sized pot, say an 8 or Io inch, so as to allow of deep planting, a most essential matter where their are upper roots to be protected. Dust a little charcoal about the bulb to keep it fresh, and cover at least two inches with soil. Water lightly until the shoot begins to appear; never apply liquid manure of any kind unless as a stimulant, when just about to flower. Among the varieties worthy of special mention for growing in pots, we would notice particularly, Auratum, Speciosum, Longiflorum, Harrisii, Tenuifolium and Candidum. Other excellent sorts for pots are Browni, Krameri, Chalcedonicum, Batemanice, Wallacei, Monadelphum, etc.

\section{LILIUM HARRISII. (Easter Lily).}

Pot bulbs as soon as received, using pots about twice the diameter of the bulb. If planted in August and pots set out doors with a covering of 4 to 6 inches of litter, they will be rooted and ready to bring into the house by October, where, if they are kept in a temperature of from $55^{\circ}$ at night to $70^{\circ}$ during the day, they will be in flower by Xmas. A succession of bloom is obtained by bringing into the house a supply as wanted, but bear in mind that Harrisii is not hardy, and requires protection if kept out doors after cold weather sets in.

\section{Pirst Size}

Extra size

Mammoth

$$
\begin{array}{rr}
\text { Each. } & \text { Doz. } \\
\$ 0.10 & \$ 1.00 \\
.15 & 1.60 \\
.30 & 3.50
\end{array}
$$$$
\cdot 30
$$

\section{LILIUM LONGIFLORUM.}

Produces fewer flowers but of better substance than Lilium Harrisii. It is grown in large quantities for Eister decoration, and requires the same treatment as that sort.

Sizes and Prices same as Lilium Harrisii.

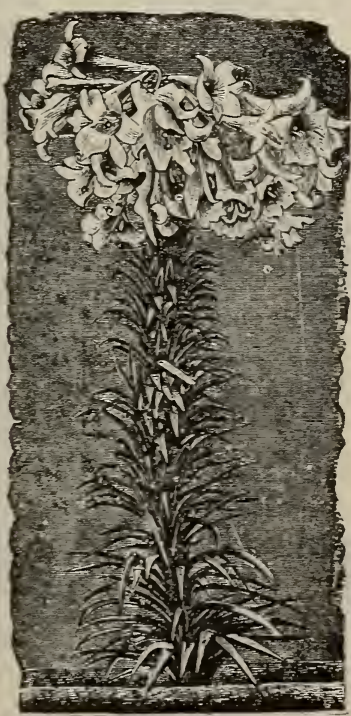

Lilium Harrisii. 


\section{LILLIES.-Continued.}

Auratum. (Golden Rayed Lily of Japan.) Ivory white Each Doz. ground, thickly strewn with purple studs; the centre of each petal has a band of light golden yellow, extending from tip to base. The most magnificent of lilies.

Auratum Rubrum - Vittatum. In this form of Auratum, the band is crimson instead of yellow, and the blotches are large and chocolate brown in color.

Batemanniæ. Clear orange apricot, without spots, six to eight flowers borne on a stem four feet high.

Browni. Trumpet shaped flowers ten inches in length, interior pure white with chocolate colored anthers, exterior brownish purple; height, three feet.

Canadense. (Canadian Bell. Flowered Lily.) Color varies from reddish orange to yellow, thickly matked with black spots; height, three to four teet.

Candidum. (The Madonna Lily.) (White Garden Lily.) Pure white, good for both pot and garden cultivation; height, four feet.

Chalcedonicum. Beautiful, deep scarlet; height, three feet.

Concolor. Fiery, scarlet flowers, faintly s potted with black; height, two feet.

Croceum. Large umbels of orange colored flowers, thickly spotted with black; height, three feet.

Davuricum Erectum. Flowers scarlet, shaded with yeilow, in umbels of eight to ten on each stem; height, three feet. (Synonyms, "Umbellatum" and "Fulgens.").

Davuricum Grandiflorum. Crimson, passing to orange, very large flowers; height, three feet.

Elegans Atrosanguineum. Rich, blood crimson, spotted with black; height, two feet.

Elegans Citrinum. Beautiful, light Each Doz. yellow flowers; height, one foot. $\quad .15 \quad 1.50$

Hansoni. Outside, yellow, streaked with white; inside, bright yellow, spotted with purple; height, three feet.

Humbolti. Rich, golden yellow, freely spotted with crimson-purple, the tips are beautifully re-curved; height, six feet.

Krameri. The flowers are six to eight inches in length, of a lovely rose color and very fragrant; height, three feet.

Leichtlinii. Pure canary yellow, with crimson spots; height, three feet.

Martagon. (Turk's Cap Lily.) Bears a pyramidal head of Howers, purple, spotted with black; height, four feet.

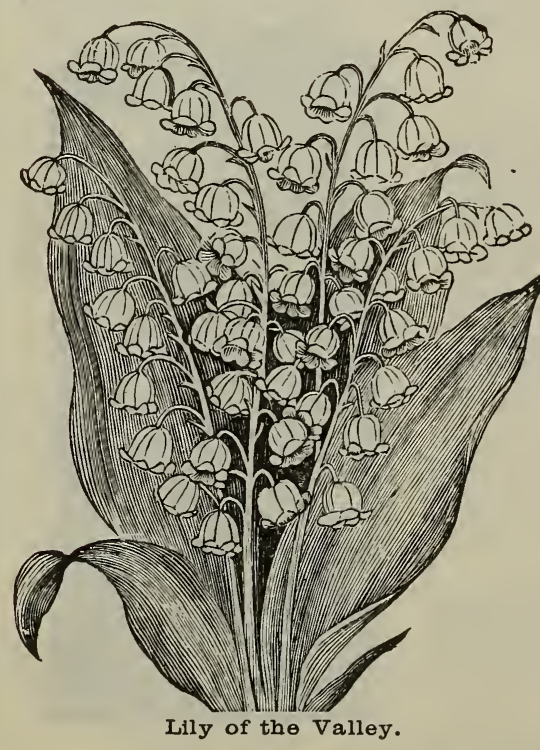
from deep, golden yellow to clear prim -

Monadelphum Szovitzianum. (Syn- Each Doz. onyms, "Colchicum," "Swoivitzia. num.") The flowers vary in color rose, spotted more or less with biack; height, three feet.

Pardalinum. Bright orange-scarlet, shading to orange, fieely spotted with maroon; height, six feet.

parryi. Clear, lemon yellow with smail purple dots at the base, very fragrant;

$.25250 \quad \begin{aligned} & \text { height, three feet. } \\ & \text { Philadelphicum. Bright red with black }\end{aligned}$ spots; height, three feet.

.404 .00 Specios um Rubrum. (Synonym, "Lancifolium Rubrum.") White, heavily spotted with rich crimson; height, three feet.

Specicsum Rubrum Melpomene. The darkestof the Speciosum group, white, heavily spotted witl dark crimson; height, th ree feet.

Speciosum Roseum. White, stainedand spotted rose; height, three feet.

Speciosum A Ibum. Large, white flowers, of great substance, with a greenish band through the centre of each petal; height, three feet

Superbum. Yellowish red; height, four feet.

Tenuifolium. (Coral Lily of Siberia.) One of the earliest, forces readily, iz to 20 fiery scarlet flowers, borne on slender stems; height, 18 in.

Testaceum. (Synonyms, "Excelsum," "Isabel. linum )" Very fragrant, apricot-colo:ed flowers; height, five feet.

Tigrinum Splendens. (Tiger Lily.) Fiery scárlet flowers, spotted crimson, the best of the tiger lilies; height, six feet. . . .

Tigrin u m Floro Pleno. Double flowered, orange, spotted black; height, three feet.

Wallacei. Glowing apricot, freely spotted with black, a magnificent variety, very distinct and effective; height, three feet.

Wallachianum Superbum. Primrose, streaked with purple; height, five feet.

\section{Lily of the Valley.}

This favorite is perfectly hardy, and does well in any moderately moist soil. When forced, the roots must be firmly planted, and the crowns well covered with soil or moss at first. Berlin Single Crowns or Pips, per doz., .25; per 100, $\$ 1.50$ Clumps, imported, large and fine, each, .30; per doz., 3.50 


\section{GENERAL ALPHABETICAL LIST}

\section{.. OF .. \\ BULBS AND ROOTS}

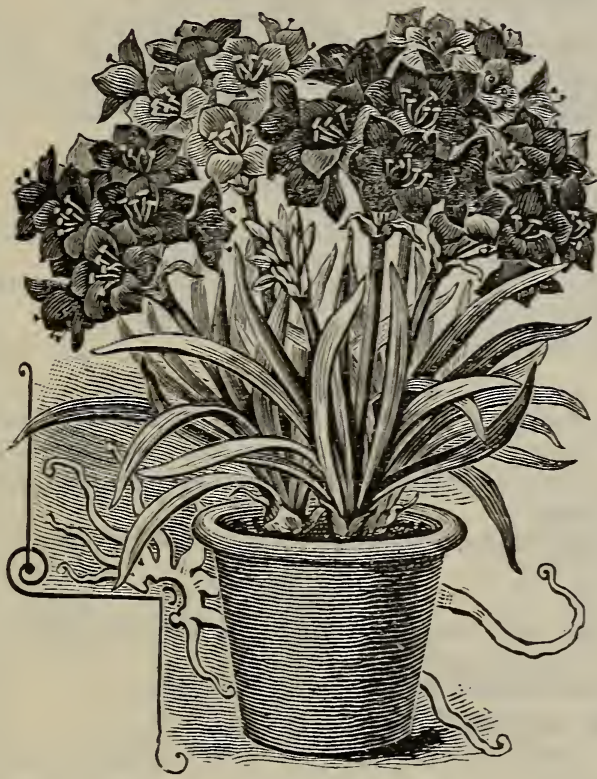

Thcse marked with a (*) ripen late, and cannot be sent out before the end of November.

\section{AMARYLLES.}

$B^{\text {UL }}$ BOUS plants with large, drooping, bellshaped, lily-like flowers, varying in color from the richest crimson to pure white, striped with crimson or scariet. The Vittata Hybrids are magnificent pot plants, thriving well in an ordinary parlor. They should be in every collection. None of them will stand the winter out of doors, but some of them may be planted out in May and will flower quite freely during the summer montlis. As pot plants for parlor and conservatory decoration during winter, they are probably unsurpassed by any other genus.

Amaryllis Vallota Purpurea.

Bella Donna. (Bella Donna Lily.) Each Doz. White, flushed with rosy purple. $\$ 0.15 \$ 150$

Formosissima. (Jacobean Lily.) Vel. vety crimson, a desirable border plant.

Johnsonii. Deep red and white.

Longiflora, alba and rosea.

Lutea. (Sternbergia.) A handsome, showy, yellow, autumn flowering

Nerine Sarniensis. (The Guernsey

Lily.) Brilliant, dazzling scarlet.
Nerine Crispa. Rose colored flowers, petals undulated at the margin; a charming pot plant.

Vittata. Magnificent varieties, flaked and striped with the most striking tints.

$\$ 0.15 \$ 150$

$.25 \quad 3.00$

0 bulb. Sarniensis. (The Guernsey

$\begin{array}{ll}\$ 0.15 & \$ 150 \\ .10 & 1.00 \\ .25 & 3.00 \\ .15 & 1.50 \\ .10 & 1.00 \\ .20 & 2.00 \\ .30^{\circ} & 3.00 \\ .50 & 5.00\end{array}$
scarlet lily-like flowers, in heads of five or six blooms each, which remain a long time in perfection. -

Zeyphranthes Rosea. Very fine; procolor.

Zeyphranthes Treatea (Fairy Lily.) A native of Florida, and h.ts recently been introduced to cultivation, and is known as the "Fair Lily." The flower stalks vary in length from seven to twelve inches in height. The flowers are solitary, strong bulbs often giving two or more flowers, which are pure white and deliciously scented.
Vallota Purpurea. Large, crimson

Eich Doz $\$ 0.25 \div 2.75$ $.0+\quad .35$

ADONIS VERNALIS.

A hardy, perennial, May-blooming, border flower. Beautiful, cup-shaped, yellow flowers. 7 cents each, so.6o per doz.

\section{ALLIUMS.}

Azureum. The best of the tribe of Allium. Fluvers deep azure blue, $7 \mathrm{cts}$, each, $60 \mathrm{cts}$. per doz Neapolitanum. Large heads of pure white flowers. 3 cents each, 15 cents per dozen.

Luteum (Moly). Hardy border plant, bright yellow thowers. 3 cents each, 5 cents per dozen.

\section{ANEMONES. - Windflower.}

These are a little tender, and if planted out doors should receive a good covering before the ground freezes. For pot culture use six-inch pots, which will contain from 


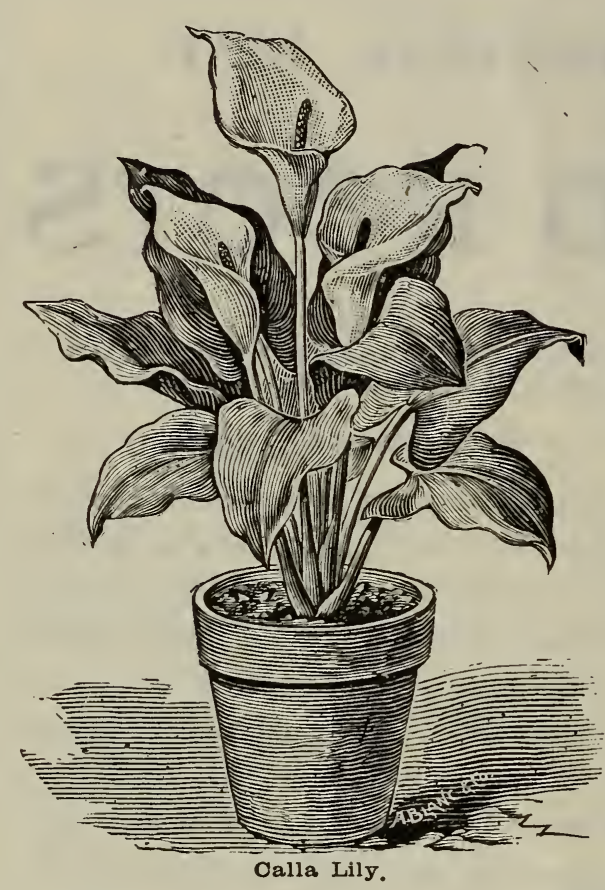

four to six bulbs. Keep moderately cool, and give but little water until the plants appear. Chrysanthemum Flowered. The best Each Doz. 100 of the double. Many colors $\begin{array}{lllll} & .05 & .35 & \$ 2 & 50\end{array}$ King of Scarlets. Very double, intense red \begin{tabular}{lll}
.05 & .35 & 20 \\
\hline & 2.00
\end{tabular} White Ceres. Double, pure white $\begin{array}{llll} & .03 & .20 & 2.00\end{array}$

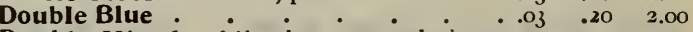
Double Mixed. All colors, very choice $\begin{array}{llll}0.03 & .20 & 1.00\end{array}$ Single Blue $• \quad \cdot \quad \cdot \quad \cdot \quad \cdot \quad \cdot .03 \quad .20 \quad 1.00$

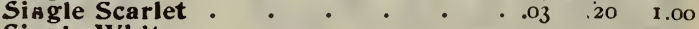

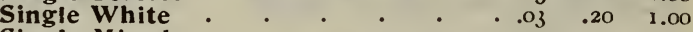

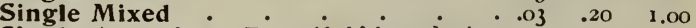
Single Appenina. Beautiful blue, desira-

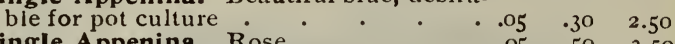
Single Appenina. Rose . . . . . . .05 $\quad .50 \quad 3.50$ Single Appenina. White . $\quad . \quad . \quad .05 \quad .30 \quad 2.50$ St. Brigid (Irish Anemone.) $\quad . .05 \quad .45 \quad 3.00$ Single Fulgens. The Scarlet Windflower .03 $\quad .20 \quad 2.00$

\section{ARUM.}

Very ornamental and interesting plants.

Dracunculus. Dragon Arum. Flowers Each Doz. $\begin{array}{lll}\text { brown, leaves resemble a sniall palm } & .15 & 1.50\end{array}$

Italicum. Large, green leaves, veined with white ' Black Calla sweet scented about a font in length and six inches broud, brilliant, dark purple color .

\section{BABIANAS.}

A group of dwarf growing plants, whose flowers range through all the various shades of blue and crimson. Admirably adapted to pot culture.

Finest Mixed. Five cents each, 25 cents per dozen, $\$ 2.00$ per 100 .

\section{BRODI $A$ EA.}

Half hardy bulbs, natives of California, especially suitable for pot culture. They bear clusters of long tubular flowers. Height, one to two feet.

Brodiæa Grandiflora. Bluish purple. Three cents each, zo cents per dozen, $\$ 2.00$ per 100 .

\section{CALLA LILY. - Lily of the Nile.}

The Calla, or Richardia Athiopica, is a well-known plant of easy culture, and in winter is one of the best of our window plants.

Richardia Athiopica. White Calla. Richardia AEthiopica Nana. Little Gem. Similar to the above, but of much divarfer habit. $\begin{array}{r}.12 \\ .20\end{array}$ CALOCHORTUS.

California Butterfly Tulip or Mariposa Lily. This genus contains some of our gayest and most beautiful half-hardy bulbs. The flowers resemble a tulip somewhat in shape, and are of brilliant colors. Ther succeed well when grown in pots. Should be protected, in Northern states, if grown in open ground.

Albus. Pearly white, with rich blotch . . . . . . . . $5050 \%$ Benthami. Yellow, with black spots . $\quad \therefore \quad .05 \quad .403 .00$ Lilacinus. Pale lilac .

Venustus Pictus. White, gold blotch

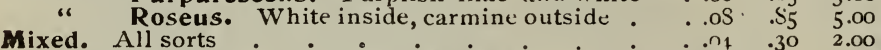

CAMASSIA. - The Quamash of the Indians.

An excellent border plant, especially effective when grown in clumps. The flowers are produced in long, graceful, loose racemes; color, blue or purple. I 5 cents per dozen; \$I.0o per Ioo.

\section{CHIONODOXA. - Glory of the Snow.}

One of the best really hardy, spring-flowering plants. Valuable for edging, also for pot culture. Each Doz. 100 Lucilliæ. Sky-blue with white centres, ten to fifteen flow -
ers borne on a stem Gigantea. Resembles the above, but with licrger flowers. .03 ..

\section{COLCHICUM.}

These beautiful, hardy flowers resemble the crocus, but bloom late in the autumn; the leaves appear the following spring.

A utumnale. Mixed colors, five cts. each, 45 cts. per doz., $\$ 3.00$ per 100 .

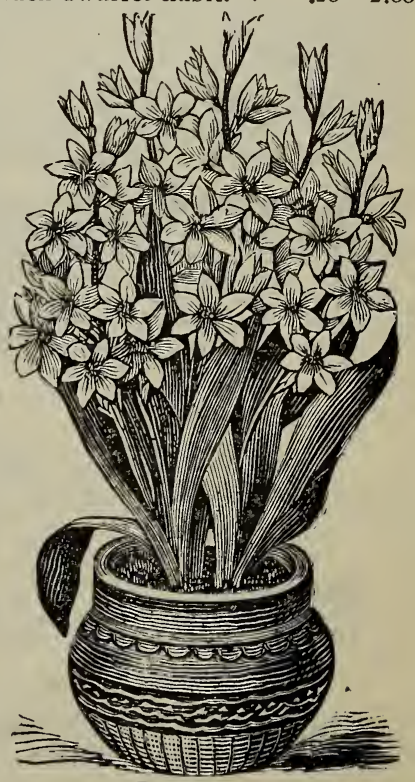

Babianas. 


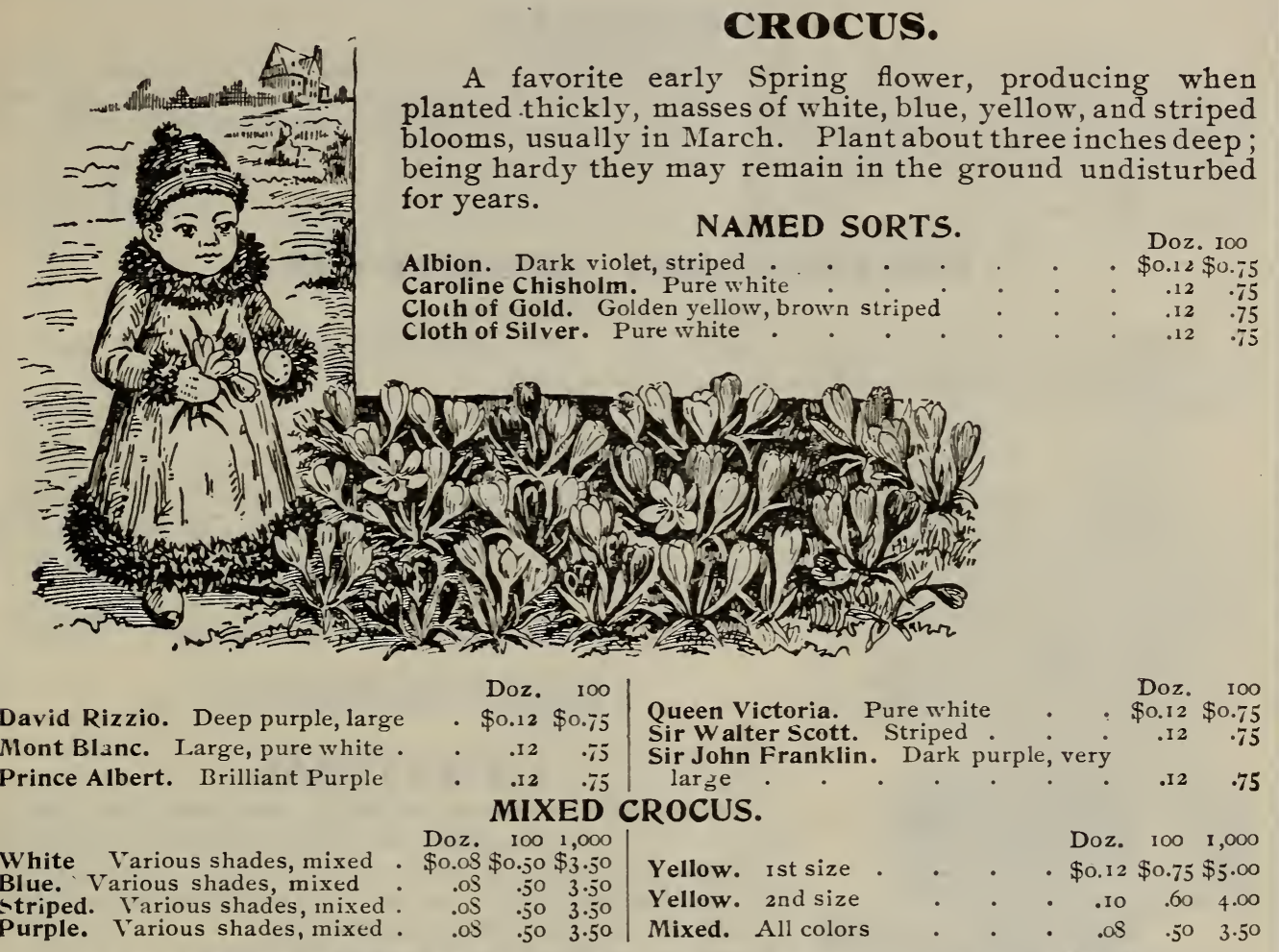

\section{CROWN IMPERIALS.-Fritillaria Imperialis.}

Stately border plants, growing about three feet high with a crown of pendant bell-shaped flowers of various colors. Plant four inches deep in good garden soil.

A urora. Light orange

Each. Doz.

$\$ 0.20 \$ 2.00$ Goid Striped.

Each. Doz.

Crown on Crown. Ked.

Doub e Red.

Double Yellow.

.202 .00 Maximum Red.

$.40 \quad 3.00$

$\begin{array}{llllll}.50 & 5.00 & \text { Sulphurine. Orange, dark striped } \quad .20 \quad & 2.00\end{array}$

CYCLAMEN.

A charming class for parlor and conservatory decoration, being remarkable for their great substance and rich colors. Pot in leaf mould and loam.

Persicum Giganteum. Album, Roseum, Rubrum, White Ṙose Eye. Separate or mixed. Each 25 cents, dozen $\$ 2.50$.

\section{*DIELYTRA, OR DICENTRA-B1eeding Meart.}

Hardy spring-flowering plant. The flowers are borne on long, gracefully curved stalks; delicate rose-colored and white, with purple lip.

Spectabilis

\section{ERANTHES}

(WINTER ACONITE)

One of the earliest harbingers of spring, when established forming sheets of large glistening yellow flowers. It grows freely under deciduous trees among grass, or in fact in almost any position or soil. A grand plant for naturalizing.

Eranthes Hyemalis

Doz., 10 cts.; hund., $\$ 0.75$

\section{ERYTMRONIUN \\ (DOG'S TOOTH VIOLET)}

A charming group of spring-flowering bulbous plants, perfectly hardy, the foliage is variegated, and the numerous Cyclamen-like flowers are large and very bright, varying in color from pure white to deep purple.

Erythronium dens=canis. Mixed . . . . . . . . . Doz.; rocts.; hund., \$0.75 


\section{FREEZIAS.}

Of decided value both for parlor culture and for forcing for cut flowers. The flowers are tube-shaped, pure white, blotched with yellow on the lower petal, and are borne on a slender branching scape, from twelve to twenty inches high. It has a very delicate, sweet perfume, and is easily forced.
Refracta Alba. Extra large
Eich. Doz. 100
$\$ 0.0 ; \$ 0.25 \$ 1.50$
Refracta Alba. Second size
Each.'Doz. 100 $\$ 0.03 \$ 0.15$ \$o.So

\section{FRITILLARIA MEIEAGRIS.}

(GUINEA HEN FLOWER.)

Valuable for pots, borders or rockwork. The large, pendant, bell-shaped flowers are striped and splashed in a most fantastic manner.

Finest colors, mixed. Each .04 Doz..35 | Pure white

Each .oS Doz. .So

\section{* GLADIOLUS.}

These are the early flowering sorts, and are valuable for both garden and greenhouse cultivation. They force readily and are grown largely by florists for bouquet work. If planted out doors a dry spot should be selected, and a heavy covering of leaves given them before frost.

Colvilli. Crimson purple, striped with white, very showy

Colvilli Alba. (The Bride.) The spikes each bear eight to tivelve pure white flowers; forces readily, and keeps well when cut.

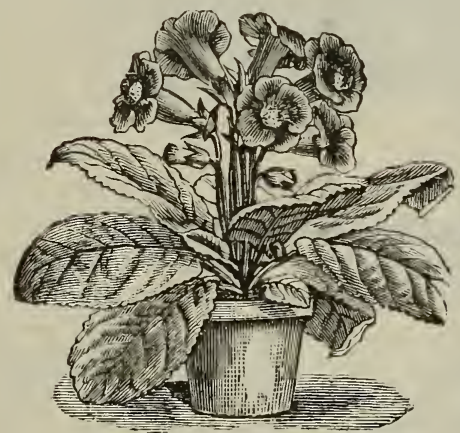

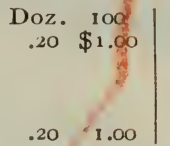

Floribundus. White, purple striped .

Queen Victoria. Scarlet and white

Ramosus. Bright saimon, rose and

\section{GLOXINIAS.}

Doz. 100

$.35 \$ 250$

$.30 \quad 2.00$

$.25 \quad 1.50$

Our strain is an exceedingly fine one; the colors being very varied, some of thein intense, glowing crimson, some purple, some pure white, others richest lilac, and some with various shades blended. They cannot fail to give great satisfaction. Each Doz. Choicest soris, mixed $\cdot$. $\quad .15 \$ 150$ Choicest sorts, mixed. Extra large bulbs : : $\quad \begin{aligned} & .25 \\ & 2.50\end{aligned}$

\section{* TEELIEBORUS NIGER. (THE CHRISTMAS OR LENTEN ROSE.)}

A beautiful half hardy herbaceous plant, flowering in great profusion early in spring, and if grown in the house or in frames will bloom during the Christmas holidays. The flowers, two to three inches in diameter, range through all shades of white, red, rose and purple, and some are spotted and shaded with other colors, making them charmingly beautiful. 25 cents each, $\$ 2.5^{\circ}$ per dozen.

\section{* IA A A IRIS. (IRIS KAEMPFERI.)}

A new group of Japan Iris. They prefer sunny, moist situations, planted in loam, where they soon become established, and form striking and very ornamental objects. Fine Mixed Sorts . . Each .15 Doz.\$1.50 | Named Varieties . . Each .25 Doz.\$2.25

\section{IRIS (Fleur de Lis).}

Elegant free-flowering bulbs, fine for beds or borders. They are all hardy, except Pavonia and Susiana, which are suitable for growing indoors in pots. Set the bulbs in clumps two inches apart each way, and three inches deep.

Iris Anglica. (English Iris.) A Each Doz. 100 Iris Persica. (Persian Iris.) Beau- Each Doz.

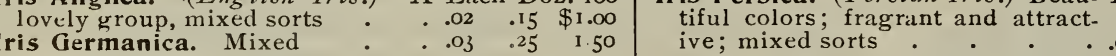
Iris Germanica. Mixed $\quad: \quad .03 \quad .25 \quad 1.50$ Iris Germanica. Separate colors. $\begin{array}{lll}\text { Blue, white or yellow } & \\ \text { Iris Hispanica. (Spanish Iris.) }\end{array}$ These are especially suitable for forcing. The plants are of divarf habit, and the flowers sweetly perfumed. The colors range through yellow, bronze, blue, purple, white and combinations of these. If planted out doors a heavy mulch covering is necessary. Colors separate or mixed

Iris Pavonia. (Peacock Iris.) Pure white, with blue spots; beautiful . .03 $\quad .20$

Iris Susiana. (Chalcedonian Iris.) Large blush-colored flowers, tinted with brown, and closely netted with dark lines . $\cdot$.

Iris Tuberosa. (Snake's Head Iris.) Rich velvety-black and green flow-
ers.. .03 


\section{ISMENE.}

Fragrant, free-flowering plants, excellent for pot culture. They require a strong, loamy, well-drained soil, and plenty of pot room. Plant the bulb just under the surface and give plenty of water - keeping always carefully moist.

Ismene Calathina. A very stately and Each Doz. ornamental plant, bearing large, white, trumpet-shaped flowers, delightfully fragrant

Ismene Undulata. Pure white, beauEach Doz. .15 \$1.50 tifully fringed; a delicate and showy

\section{IXIA.}

Charming half-hardy plants, of dwarf growth. Will grow well in the parlor or conservatory. Protect from frost. Water freely.

Ixia, Golden Drop. Yellow tinged purple, deep maroon Doz. 100 xia Creteroides. New iarge flowering variety, with Ixia Creteroides. New iarge flowering variety, with
bright scarlet flowers; very effective

Ixia Viridiflora. Green, spotted at base, very beautiful. This and the preceding variety are very largely grown by florists for cutting.

Fine Mixed Varieties. Various colors

\section{LACHENALIAS.}

Pretty, and easily grown greenhouse bulbs. They should be potted in September and left in the open air until end of October, then remored to the house; they give continuous flower during winter.

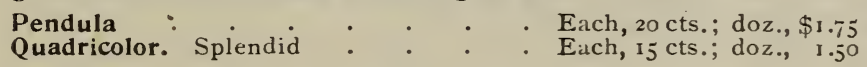

\section{MADEIRA VINES.}

Beautiful climbers for window culture during winter; pretty bright green foliage and small, yellow, fragrant flowers. Each, 5 cts.; doz., 50 cts.

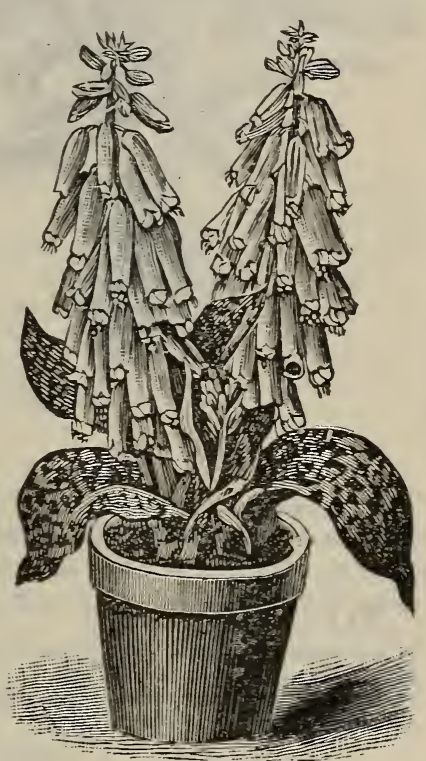

Lachenalia.

\section{ORNITHOGALUM.}

A rabicum. A beautiful bulbous plant of fine habit. The numerous fragrant flowers are borne on spikes eighteen inches high. Desirable for house culture and forcing . $\quad .03 \quad .25 \$ 2.00$ Umbellatum. (Star of Bethlehem). Large clusters of pure white, star shaped flowers $\begin{gathered}0.02 \\ .12\end{gathered}$

\section{OXALIS.}

Suitable for growing in vases, hanging baskets, etc. Plant in fine sandy loam, four or five together, and when done flowering keep dormant until September.

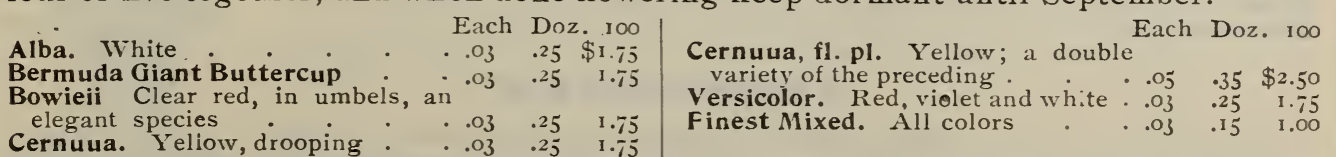

\section{HARDY PAEONIES.}

These, in many respects, are more desirable than roses. The size and form of flowers, the range of color and sweet fragrance is scarcely surpassed by any family. So far the plants are not subject to any insect pests, and they are perfectly hardy when once established. The best time to set out is from the middle of September until the middle of October.

Double Varieties, assorted. Each, 50 cts.; doz. $\$ 5.00$ | Single Varieties, assorted. Each, 5octs.; doz. $\$ 5.00$ 


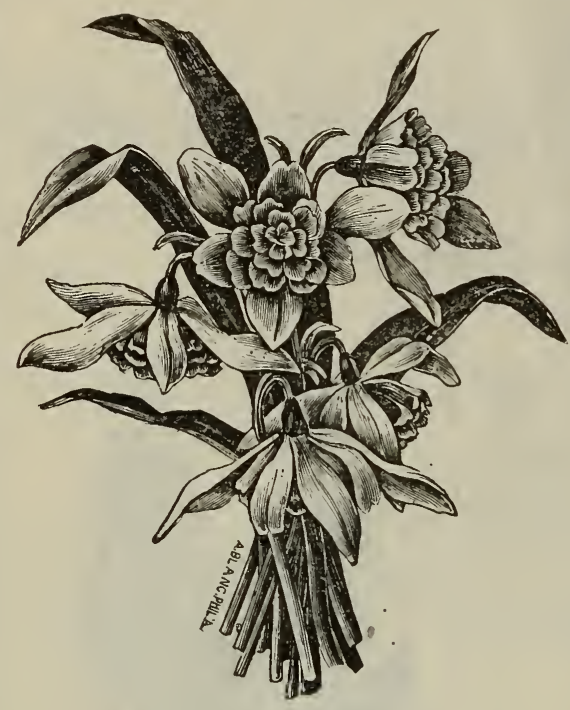

Double Snowdrops.

\section{RANUNCULUS.}

Brilliant flowers, blooming in June. They require deep, rich, loamy soil, and should have a covering of leaves or litter before winter sets in. Turban or Turkish. Very double and dis. Doz. $10 \mathrm{C}$ tinctly marked, great variety of color, comprising nearly every shade of white, crimson, yellow, purple, etc. Finest mixed.

Persian. These are as beautiful as the Turkish, but quite distinct, producing smaller flowers, and blooming later. Finest mixed

French. More vigorous in growth, and larger Howered than the Persian or Turban. Very beautiful and varied. Finest mixed $.15 \$ 1.00$ $.15 \quad 1.00$ .151 .00

\section{SNOWIROPS.}

\section{(GALANTHUS NIVALIS).}

Succeed well under the same cultivation as the Crocus. As the bulbs are small, from twelve to twenty ought to be planted in a clump. Snowdrops, Single. Extra fine bulbs
Snowdrops, Double. Extra fine hulbs
Galanthus Elwesii (Elwes' Giant Snowdrop).
A gigantic species, growing about a foot high.
The flowers are large and pure white, with
three green blotches at base of inner segment Doz. 100 $.15 \$ 1.00$ $.25 \quad 1.50$

$.15 \quad 1.00$

\section{SCILLAS.}

A family of very pretty small bulbous plants, flowering about the same time as the Crocus and Snowdrop. They are quite hardy, and admirably adapted for forcing, edging, inassing, etc., and also for growing indoors.

Scilla Siberica. (Syn: Amena Precox). Brilliant sky blue; should be planted in clumps for Doz. roo good effects

Scilla Campanulata. Blue, on long spikes

Scilla Campanulata. White

Scilla Peruviana. Blue, large pyramidal heads, six inches across :

Scilla Peruviana Alba. White

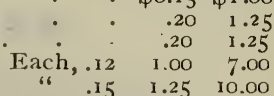

\section{SPRING SNOWILAKE.}

\section{(LEUCOJUM VERNUM.)}

A beautiful early blooming plant, resembling the Snowdrop. Per doz., $25 \mathrm{cts}$.

\section{SPARAXIS.}

Brilliant and attractive flowers, embracing every shade of crimson, scarlet and white; mottled, striped and splashed in every conceivable manner. Per doz., I5 cts.; per IOO, $\$$ I.00.

\section{SPIR IEA OR ASTILBE.}

Not subject to either of our Special Offers.
Astilboides Floribunda. A much improved form; divarf, early and free flowering. The flowers keep well when cut

Japonica. Numerous crowded panicles of feathery white flowers.

the flowers are finer

Palmata A Iba.

\section{TROP AEOLUN.}

Plant in pots, use a light rich soil, with plenty of drainage ; just cover the tubers, and when started keep up a vigorous growth; a ten or twelve inch pot will be required for one bulb.

Jarratti. Scarlet, yellow and black

Speciosum. Scarlet and orange

\section{NEW BOOK ON BULB CULTURE.}

By C. L. ALLEN. Handsomely lllustrated and Well Bound. Price \$2.00.

This is the only really practical, low priced work on Bulbs and Tuberous-rooted plants published in America. It contains their history, description, methods of propagation, and complete directions for their successful culture in the garden, dwelling and greenhouse. 


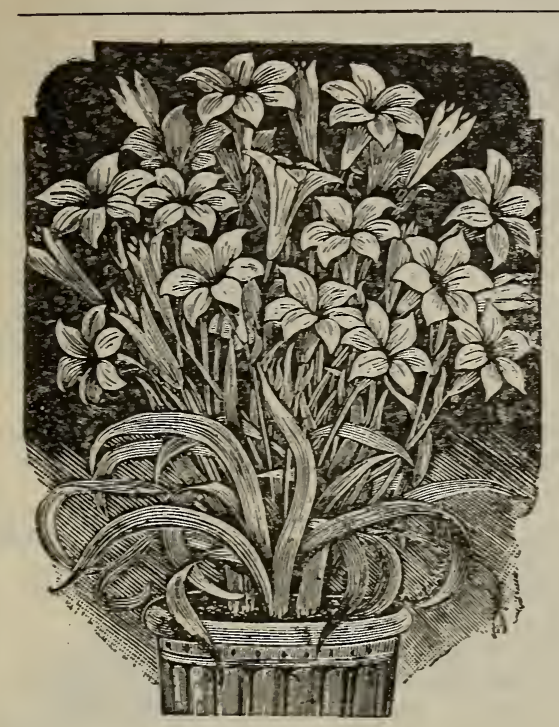

Tritelia.

\section{TRIILIUM. (Wood Lily.)}

One of the most effective of our early spring flowering perennials; perfectly hardy, and will grow freely in any cool and shady place.

Trillium Grandiflorum. (The Wood Lily). White. Each, 15 cts.; doz., $\$ 1.50$.

\section{TRTTONIA.}

Plant four or fire bulbs in a pot six inches in diameter, and corer them one inch deep. Cultivate the same as for Ixias.

Tritonias. Fine mixed varieties. Each, 5 cts.; doz., 40 cts.

\section{TRETELIA UNIFLORA.}

A charming spring flowering plant, growing about six inches high, producing large flowers on slender stalks. Increases rapidly, and can be used advantageously for lines, edging beds, or in clumps on the rockery or borders.

Uniflora. Pure white, blue shaded. Doz. 20 cts.; roo, \$r.50 WE OFFER THESE SUGGESTIONS FOR ARRANGING BEDS OF TULIPS.

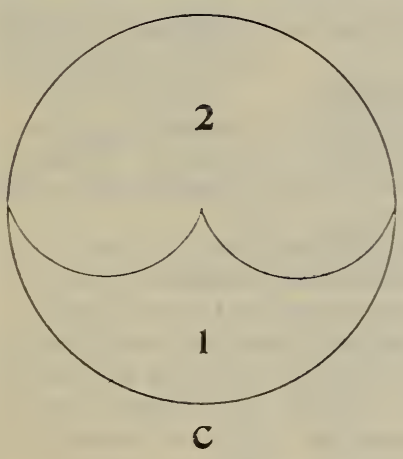

I 42 Pottebakker, White.

$2 \mathrm{~S}_{1}$ Pottebakker, Scarlet.

Price for 126 Bults, $\$ 1.60$

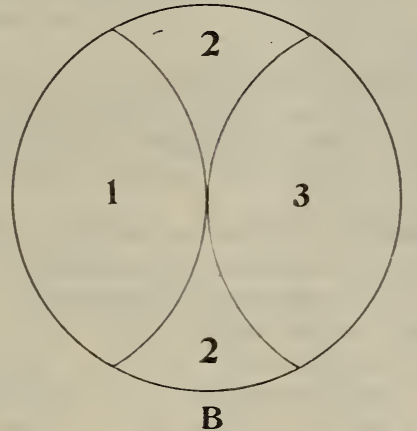

I 42 Royal Standard, Gold Stricéd.

242 Queen of Violets, Light Tiolet.

342 Royal Silver Standard, White and Rosy Crimson.

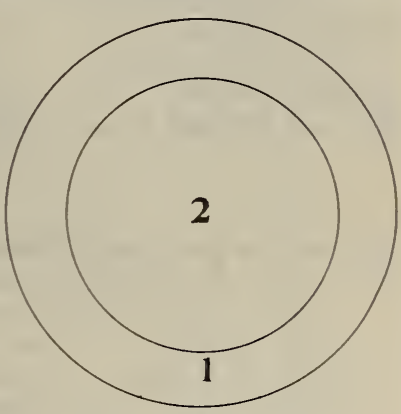

D

I 66 Cottage Maid, Rose Pink, Shaded White.

260 Proserpine, Rich Dark Rose.

Price for 126 Bulbs, $\$ 1.70$

Price for 126 Bulbs $\$ 185$.

The number of bulbs is figured for beds each 6 feet in dianeter. The same arrangements would apply for either larger or smaller beds of similar design.

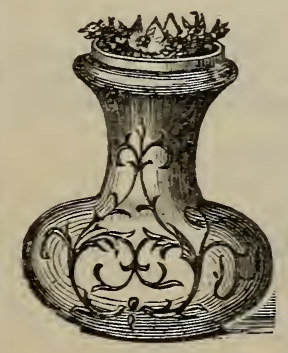

\section{HYACINTH GLASSES.}

The Hyacinth Glasses we offer are of American manufacture. They are of better shape and in more desirable colors than the imported Belgian glasses usually sold.

Ordinary Tall Shape; green, blue and amber

Each. Doz. Tye's Style, (Shape of Cut), green, blue and violet $\quad .20 \quad 2.00$ Special offer No. 3 only applies to Hyacinth Glasses

\section{PEAT, LEAF MOULD, ETC. FOR BULBS AND PLANTS.}

(Not subject to Special Offers.)

Rotted Fibrous Peat. $\frac{1}{2}$ peck, $20 \mathrm{cts.;}$ peck, $30 \mathrm{cts.;}$ bus., $\$ 1.00$; bbl., $\$ 2.00$.

Leaf Mould. $\frac{1}{2}$ peck, 20 cts.; peck, 30 cts.; bus., $\$ 1 . c 0: b^{1}, 1.12 .00$

Prepared Bulb Soil. Specially prepared with Peat, Leaf Mould, Loam, Sand, and a sufficient quantity of Ferlilizer. Price, $\frac{1}{2}$ peck, $25 \mathrm{cts}$.; peck, $40 \mathrm{cts}$.; bus., $\$ 1.25 ;$ bbl., $\$ 2.50$. 


\section{SUNDRIES.}

Article on this page subject to Special Offer No. 3 only.

Aphis Punk, Nikoteen. A special preparation of nicotine for the extermination of green and black fly, thrip, etc., contains 110 ammonia and does not injure delicate plants. Per box of one dozen rolls ( 720 grains nicotine) $60 \mathrm{cts}$.

Canker Worm Exterminator. (Morrill's Tree Ink.) A sure protection to trees from the ravages of grub and canker worms. Directions with each can. 2-1b. cans, 30 cts. ; 3-1b. cans, 45 cts. ; 5-1b. cans, 60 cts. ; ro-1b. cans, $\$$ I. IO; 20-1b. cans, $\$ 2.00 ; 28-1$ b. cans, $\$ 2.80$; I 25-1b. kegs, per 1b., .og cts.; 46n.1b. barrels, per 1b., $.07 \mathrm{cts}$.

Fir Tree Oil. Soluble. An invaluable preparation for destroying all insects and parasites that infest fruit trees, plants and animals, whether on foliage or at the roots of the plants. Per gal., $\$ 4.00$; per qt., $\$$ I.25; pt., $.75 \mathrm{cts}$.; $1 / 2$ pt., 50 cts.

Fir Tree Oil Soap. This article contains no poison, yet is quite effective in destroying red spider, mealy bug, aphis, etc. 1/2-1b. tin, 25 cts.; $2-1 \mathrm{~b}$. tins, $75 \mathrm{cts}$.

Fostite. A light powder that can be evenly applied with a bellows; destroys mildew, black rot and rust. Per 5-1b. pkg., 6o cts.; 25-1b. box, $\$ 2.50$.

Tobacco Extract. Rose Leaf Brand. A perfectly pure, aqueous extract, highly concentrated and always uniform in strength of nicotine poison. Destroys green fly, mealy bug, red spider, and scale. Pts., 25 cts.; qts., 45 cts.; I gal., \$1.ro; 5 gals., $\$ 4.50$.

Tobacco and Sulphur Powder. Prevents and cures mildew. Kills green and black fly and other insects. ro cts. per $1 \mathrm{~b}$. ; $\$ 6.00$ per Ioo $1 \mathrm{bs}$.

Tobacco Dust. Very finely pulverized. A valuable insecticide and fertilizer. 5 cts. per 1 b.; $\$ 2.50$ per roo lbs. Net.

Tobacco Stems. For fumigating. \$I.00 per bb1.; \$2.50 per bale.

$\mathbf{X}=\mathbf{A l l}$ Liquid Insecticide. For syringing, spraying, dipping, or sponging. Des. troys all insects, especially effective against mealy bug and red spider. Can be used without injury in graperies, even when the fruit is in an advanced stage of growth. Pt., 65 cts.; qt., \$I.00.

$\mathbf{X L}=$ All Vaporizing Compound. This is an English preparation, that at the first glance has an high priced appearance. The safety with which it can be used, its never-failing effectiveness and the ease with which it can be applied as an insecticide, places it at the head of the first rank. It is cheaper, results considered, than any other vaporizing compound, and there is no other like it. Its action is positive on Mealy Bug, Thrip, and all kinds of Aphis. Price per bottle No. I, $\$ 8.00 ;$ No. 2, $\$ 4.25$; No. $3 . \$ 2.25$; No. 4, \$r.I5. The smallest bottle is sufficient to fumigate 5,000 cubic feet.

Fumigators. With lamp for vaporizing: large, $\$$ r.oo; medium, $85 \mathrm{cts}$.

\section{IMATS, HOT BED.}

Made in a first class manner from selected Rye Straw. The twine used is especially prepared for the purpose and is very durable. Size $6 \times 6 \mathrm{ft}$., $\$ 1.50 ; 3 \times 3 \mathrm{ft}$., \$1.00. Special sizes made to order.

\section{SCOTCH SOOT.}

This is inuch used by florists and gardeners, both as a fertilizer and fungicide. Mixed with Flowers of Sulphur (two-thirds soot, one-third sulphur), there is nothing better to prevent and cure mildew. Used as a fertilizer, either in dry state or liquid, it quickly promotes growth, and heightens the color of both flower and foliage. Per $100 \mathrm{lb}$. bag, $\$ 2.50 ; 25-1 \mathrm{~b}$. bag, $\$ \mathrm{r} .00$, net.

\section{SHEEP MA NURE.}

This is a pure natural manure, and nutritious food for plants. Its effect is immediate. It is the best of ali manures for mixing with the soil for $y$ reenhouse plants-one part manure and six parts soil. Price, in bags of 100 lbs. each, $\$ 2.00$; per ton, $\$ 35$.00. Sheep manure is net $\mathrm{f}$. o. b. Boston.

\section{TROPIK FIBRE.}

A chemically prepared vegetable fibre, rich in plant food. Its peculiar character especially adapts it to induce root growth and cause healthy, vigorous plants. For potting bulbs use one third Tropik Fibre to two thirds of the usual soil preparation and you will he surprised at the results. Tropik $F^{*} i b r e$ is unsurpassed as a medium in which to sprout seeds. Price, 5 lbs., 30 cts.; 15 lbs., 50 cts.; 25 lbs., 75 cts.; 501 lbs., $\$ 1.00 ; 100 \mathrm{lbs} .$, 1 1.50. 
Special offer No. 3 only applies to articles on this paga.

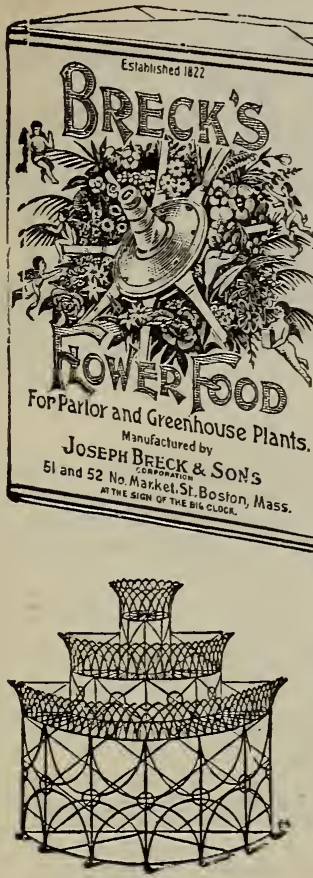

No. 4.

\section{BRECK'S FLOWER FOOD.}

A safe, clean, ordorless, concentrated plant food that is soluble in water, it promotes a healthy, vigorous growth of wood, leaf and flower.

No. I, sufficient for 30 plants for one year, 25 cts. ; by mail, 40 cts.

No. 2, sufficient for 30 plants for 3 months, 15 cts.; by mail, 20 cts.

We furnish with each package a practical treatise of 32 pages, on the care of house plants. "Success with House Plants."

\section{PLANT STANDS.}

Wire, Rigid. These stands are most desirable, either for house use, or for conservatories.

No. I. Oblong Stand, 24 in high, 30 i1l. long, $9 \frac{1}{2}$ in wide. . . $\$ 2.00$

No. 2. Square Stand, with 2 shelves 33 in. high, 18 in. deep, 33 in. long 3.00 No. 3. Is like No. 2. but has 3 shelves, $36 \mathrm{in.high.} 24 \mathrm{in.}$. leep, 33 in. long. . 3.75

No. 4. Semicircle Stand, 36 in. high, 26 in. deep.

For other styles see our General Catalogue.

WIRE WINDOW SHELF.

With adjustable steel brackets: 36 inches

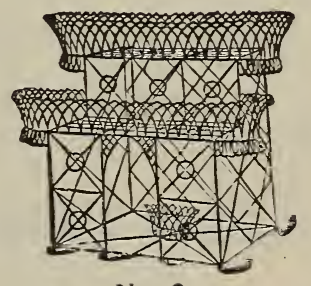

No. 2. long, with brackets complete, $\$ 1.00$; each additional foot 35 cents.

FLOWER PO'TS AND SAUCERS. Inside Measurement, width and depth equal. Pasking charged extra.

FLOWER POTS.

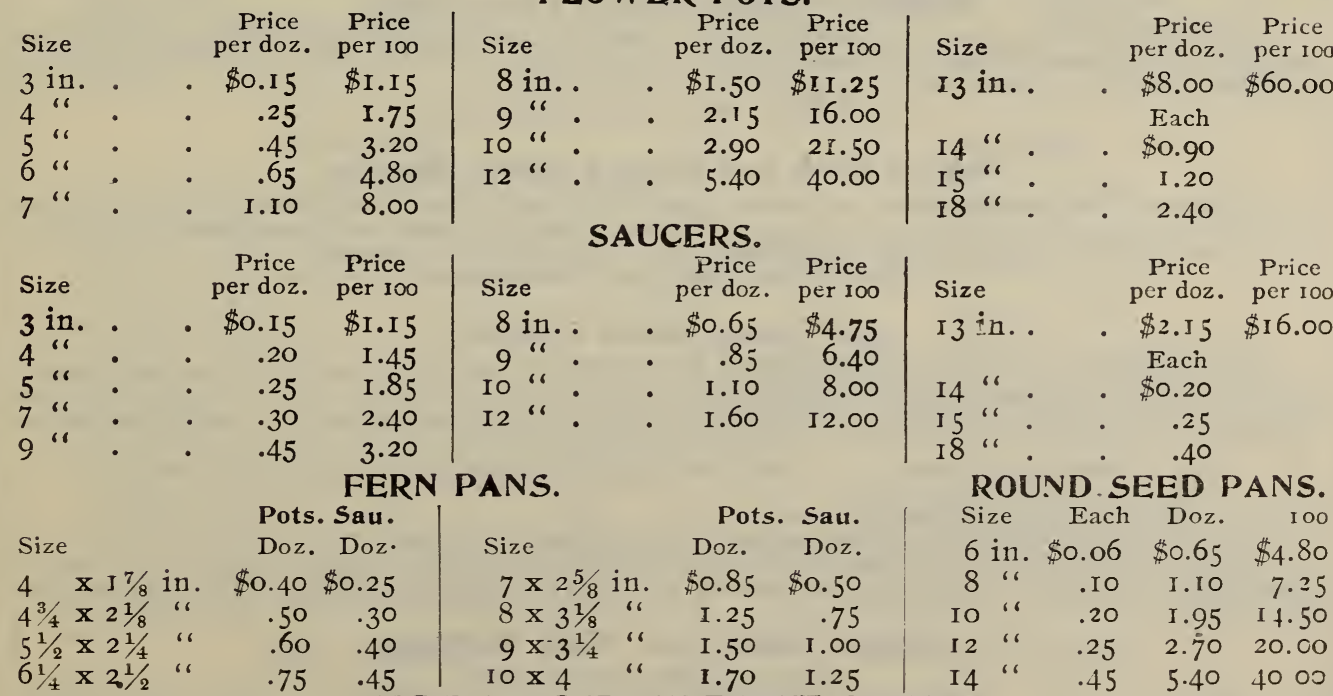

\section{FIBRE SAUCERS WITHOUT CASTORS}

Made from Indurated Fibre Ware, prevents moisture passing through to injure table, floor or carpet.

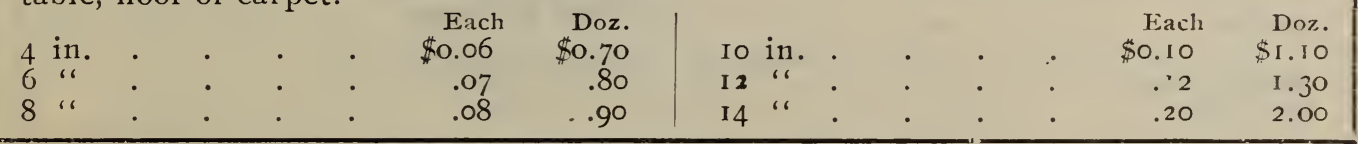




\section{CEDAR PLANT TUBS.}

For growing Agaves, Century, and other large plants. Made of the best red cedar; painted green; iron handles.

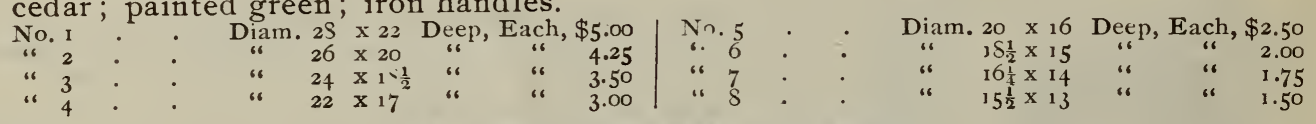

\section{OAK PLANT TUBS.}

Natural wood finish. These are strong, light, and thoroughly serviceable. I 2 inches diameter, 11 inches high

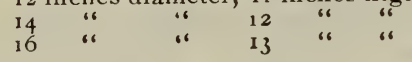

Wese are strong, light, and thoroughly service

\section{GRASSES.}

There is no better season in which to renovate a lawn that is burned or wearing out than from the middle of August until the end of September. Rake out the dead roots, moss and useless surface covering. Sow Breck's Standard Lawn Grass at the rate of two bushels to the acre, rake lightly and roll well. The dew, and cool nights together with the warmth of the days soon starts growth and carries it to perfection before winter sets in.

\section{Breck's Standard Lawn Grass.}

One quart will sow 300 square fect. Quart, $\$ 0.25$

One half peck will sow I, 200 square feet. $\frac{1}{2}$ Peck, .75

One peck will scw 2,400 square feet. Peck, 1.25

One bushel will sow 10,000 square feet. Bushel, 4.00

\section{Boston Park Lawn Grass.}

The same mixture of grass «s and clovers as supplied by us to the City of Boston Park Commissioners for sowing on the Franklin and other Parks administered by them.

$\begin{array}{lcr}\text { One pound will sow 6So square feet } & \text { Price } & \text { \$0.30 } \\ \text { Sixteen pounds will sow half acre } & \text { " } & 4.00 \\ \text { Sixty-four pounds will sow one acre } & \text { " } & 15.00\end{array}$

Our Booklet “" The Lawn, The Garden," tells you how to make and care for a lawn. Free upon applica-

We can supply other mixtures of so-called Lawn Grass Seed at competitive prices,but we recommend our own as being superior in every respect to all others. When desired we make special inixtures of Grasses to suit different soils and conditions.

\section{Breck's "Shady Spot" Lawn Grass.}

This is a mixture of grasses that are naturally adapted for growing under trees and in places where the sun does not find ready entrance. If sown on such locations, in place of the ordinary Lawn Seed, bare and unsightly spots will be prevented.

Quart \$0.25. Peck \$1.25. Bushel \$4.00.

\section{Breck's Bank and Terrace Grass Mixture.}

A mixture of deep-rooting grasses specially prepared for embankments and situations where it is impractical to get a successful catch of the less spreading rooted sorts. It produces a rich velvety turf throughout the season. No coarse growing undesirable varieties are used in this mixture

Quart $\$ 0.25$. Peck $\$ 1.25$, Bushel $\$ 400$.

\section{Golf Links Grass Mixture.}

Since the game of Golf became so popular in this country, we have had frequent demands for mixtures of grass seeds, suitable both for the Courses and Putting Gieens, and adapted 1o low, damp, as well as the thinner dry soils on the elevations. It will be readily understood that no one mixture would be suitable for the different conditions. We have, therefore, prepared three $111 \mathrm{x}^{\prime} \mathrm{ures}$;
No. 1. For Putting Greens.
Sow at the rate of so pounds to the acre.
No. 2. For light and dry soils.
$\begin{array}{llllll}\text { No. 2. For light and dry soils. } & \text { No. For low and damp grounds. " } & \text { " } & 50 & 4 & .12\end{array}$

We will be glad to make special mixtures for other conditions of soil, etc.

Our general Catalogue has a valuable treatise on grasses and grass mixtures. The leading kinds of grasses are described in detail and sixteen formulas for different conditions are given. We mail it free upon application.

\section{Grass Seeds for Fall Sowing.}

\section{(PRICES SUBJECT TO CHANGE.)}

Per Bushel

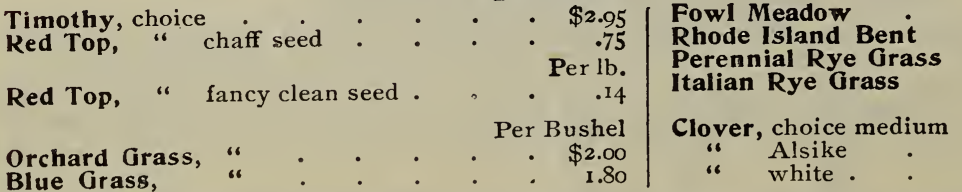

Per bushe

$\$ 2.25$

2.25

2.00

2.00

Per lb.

$\$ 0.14$

.18

Blue Grass 


\section{NURSERY DEPARTMENT.}

We continue to give special attention to this important branch of our business. Our arrangements enable us to offer advantageously leading kinds of FRUIT, SHADE and ORNAHENTAL TREES, EVERGREEN And FLOWERING SHRUBS, HERBACEOUS PLANTS, Etc., of first-class quality at reasonable prices. Parties laying out new places, or wishing to re-arrange or improve their grounds can avail themselves of our experience and advice. IVe will be glad to send a competent person to examine the grounds and advise as to changes or laying out.

HERBACEOUS PLANTS, ORNAMENTAL SHADE AND FRUIT TREES, GRAPE VINES, CURRANTS and SMALL FRUIT of all kinds get a better start if planted out in the fall, and we racommend planting at this season.

\section{SHADE AND ORNAMENTAL TREES.}

Ash, American White (Fraxinus Alba). $10 \mathrm{ft}$., 75 cents ; $12 \mathrm{ft} ., \$ 1.00$.

Ash, Mountain (Sorbus Americana). $6 \mathrm{ft}$., 50 cenıs ; $9 \mathrm{ft}$., $\$ 1.00$

Beech, American (Fagus Fernginea). $5 \mathrm{ft}$., 50 cents ; $7 \mathrm{ft}$., $\$ 1.00$.

Beech, River's Purple ( $F$. Atropurpurea). 2 ft., $\$ 1.00 ; 4$ it., $\$ 1.50$.

Birch, Cut Leaved, Weeping (Bttula Pendula La. ciniata). 5 to $6 \mathrm{ft}$., $\$ 1.00 ; 8$ to $10 \mathrm{ft}$., $\$ 2.60$.

Catalpa, Speciosa. 6 to $7 \mathrm{ft}$., 75 cents.

Chestnut, American (Castanea Americana). $4 \mathrm{ft}$., 50 cents ; $7 \mathrm{ft}$., $\$ 1.00$

Chestnut, Horse (Æsculus Hippocastrum). $5 \mathrm{ft}$., $\$ 1.00 ; 6 \mathrm{ft}$., $\$ 1.50$.

Elm, American (Ulinus Americana). $10 \mathrm{ft}$., $\$ 1.00$; $12 \mathrm{ft}$., $\$ 1.50$.

Laburnum, Golden (Cytisus). $4 \mathrm{ft}$., 50 cents ; $5 \mathrm{ft}$., $\$ 1.00$.

Linden, American or Basswood (Tilia Americana). $8 \mathrm{ft}$., 75 cents; $10 \mathrm{ft}$., $\$ 1.00$.

Maple, Cut Leaf Weeping (Acer Wierii Lacinia$t u m)$. $8 \mathrm{ft}, \$ 1.00$.

Maple, Norway ( $A$. Plantanoides). $8 \mathrm{ft} ., \$ 1.00 ; 10$ ft., $\$ 1.25$.

Maple, Sugar ( $A$ Saccharinum). $10 \mathrm{ft}$., $\$ 1.00 ; 12$ to $15 \mathrm{ft} ., \$ 1.50$.

Magnolia, Acuminata (Cucumber $M$ ). $5 \mathrm{ft}$., $\$ 1.00$.

Magnolia, Soulangeana. Nice specimens, $\$ 1.50$ to $\$ 3.00$.

\section{APPLES.}

\section{FRUIT TREES.}

Name of Month designates time of ripening.

Apple, Astrachan, Red. Early, handsome, red, pleasant, acid; white flesh. Eariy August.

Baldwin. A well-known sour winter apple. December to April.

Early Harvest. Yellow, tender, sub-acid. Bears young. August.

Gravenstein. Very large, sub-acid. September to October.

Greening, R. I. A superior cooking and eating. Mild acid. Green. December to February.

Hubbardston Nonesuch. Large, dark red striped. One of the best for eating and cooking. November to February.

Per tree one.half to one inch in diameter, five to six teet high, 35 cents, $\$ 4.60$ per dozen. One and onehalf to ?tvo inches in diameter, seven to nine feet high, in bi aring, $\$ 1.00, \$ 10.00$ per dozen, except where noted.

\section{PEACHES.}

Crawford's Early. Very large, oval, pointed, yellow, with red cheek, very juicy, sub-acid, excellent, vigorous and projuctive. Ripening early in September.

Crawford's Late. Very large, yellow, with broad red cheek, rich, juicy, vinous, and deservedly the most popular late kind. Ripening in October.

Mountain Rose. Large, roundish, free stone. Tree hardy, vigorous, productive. Ripening in August.

Per tree, 1 to 2 years, 4 to $6 \mathrm{ft}$., 25 cts.; extra large or older trees, 6 to $7 \mathrm{ft}$., $50 \mathrm{cts}$.
Mulberry, Downing's Everbearing (Murus). ft., $\$ 1.00$.

Oak, White (2uercus Alba). $\$ 1.00$ to $\$ 2.00$.

Poplar, Bolliana (Populus). Pyramidal growth. $8 \mathrm{ft} ., \$ 1.00 ; 10 \mathrm{ft} ., \$ 1.25$.

Poplar, Lombardy (P. Fostigiata). $6 \mathrm{ft}$., 50 cents ; 8 to $10 \mathrm{ft}$., 75 cents.

Willow, Great Weeping (Salix Babylonica). 6 it , 50 cents ; $8 \mathrm{ft}, 75$ cents.

\section{HEDGE PLANTS.}

Honey Locust. 2 years old. . . $\$ 6.00$ per 100

Arbor Vitae American. 2 to 3 feet 10.10 "

Hemlock. 2 to 3 feet . . . . 30.90 "“

California Privet. 2 to 3 feet . . 10.00 "6

Purple Barberry. I to I $\frac{1}{2}$ feet . . 12.00 "

\section{ROSES.}

We name here twelve of the best Hardy sorts; de. scription of these and over one hundred others will be found in our general catalogue.

Alfred Colomb.

American Beauty.

Baron de Maynard.

Jules Margottin.

La France.

Duke of Edinburgh.

Paul Neron.

John Hopper. Ulrich Brunner.

Fine strong plants, 50 cents each; $\$ 4.00$ per dozen.

\section{PEARS.}

SUMMER SORTS.

Bartlett. Large and juicy. Late.

Clapp. Productive. Large and juicy.

\section{AUTUMN SORTS.}

Beurre Hardy. October. Large green russet. Beurre Bosc. October. Large and very fine. Duchesse d'Angouleme. October. Very large. Seckel. September. Small, but fine quality.

\section{WINTER SORTS.}

Anjou. November to January. Large. High flavor. Dana's Hovey. November. Small. Rusty ye!low. Nellis. January. Medium size. Extra quality.

Vicar. December. Very large. Fine for cooking. $5 \mathrm{ft}$., 75 cents each. Larger trees, $\$ 1.00$ to $\$ 3.00$.

\section{QUINCES.}

Quince, Champion. Vigorous, upright grower, bearing young and abundantly; fruit larger than orange and best quality. Per tree, $75 \mathrm{cts}$. to $\$ 1.00$.

Meech's Prolific. A strong, vigorous grower, immensely productive, and of best quality. Per tree, 75 cts. to $\$ 1.00$.

Orange. One of the best. Per tree, $75 \mathrm{cts}$. to $\$ 1.00$. 


\section{RASPBERRIES.}

Cuthbert. One of the very best, being hardy in winter. Fruit clear red, firm, and carries we!! to market.

Goldei Queen. A sport from Cuthbert.

Gregg. The largest and best late black cap; requires generous treatment to give fine fruit.

Hansell. The earliest of all Raspberries; hardy, of vigorous growth and productive. Fruit bright crimson, very firm. The above varieties, per dozen, $\$ 1.00$, hundred, $\$ 5.00$.

\section{BLACKBERRIES.}

Early Harvest. Extra early, and of fine flavor; hardy, vigorous and productive.

Lucretia Dewberry. (Nezv). A partially trailing blackberry, juicy and rich fruit. Per dozen, \$1.50; hundred, $\$ 10.00$.

Snyder. An entirely hardy and productive kind, of good quality.

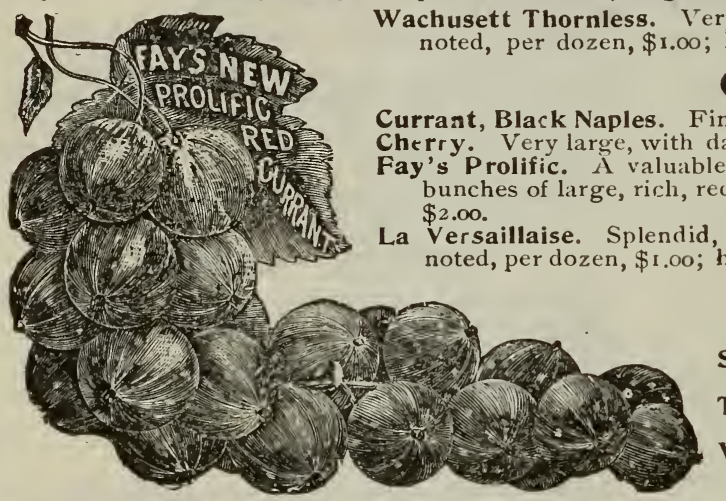

\section{CURRANTS.}

Currant, Black Naples. Fine large fruit.

Very dark red berries, rather acid.

Prolific valuable variety, remarkably productive, with very long bunches of large, rich, red colored fruit. Two year plants, 25 cents; doz. (2.00. noted, per dozen, $\$ 1.00$; hundred, $\$ 5.00$; thousand, $\$ 30.00$.

\section{GRAPE VINES. For the Open Ground.}

Grape Vines, Brighton. Excellent quality; bunch large, berries red.

Concord. Acknowledged to be " the grape for the million."

Delaware. A sinall, but very delicious, red grape; very hardv.

Eaton, New Black. Hardy, vigorous, productive, healthy. Clusters weigh from ten to twenty-five ounces. Per vine, two-year vines, $\$ 1.00$; one year, 50 cents.

Green Mountain. An extra early seedling from Vermont, remarkable for its health, vigor and productive. ness; quality is unsurpassed.

Moore's Early. A large, early, and handsome grape. Has all the good points.

Niagara White. The vine is remarkably hardy; bunches very large. Ripens with the Concord. It is enormously productive.

The above Hardy Grapes are all strong, healthy, two-year vines. Per vine, 50 cents; one year, 35 cents; except where noted.

\section{POT GROWN STRAWBERRY PLANTS.}

The earlier they are planted the larger the first season's crop will be. The plants may be set in beds of three rows, one foot apart, and one foot distant in the rows, with a suace of about three feet betwcen the out. side rows of adjoining beds left for a pathway, or they may be planted in rows three feet apart and one foot apart in the rows.

Where the winters are severe, with little snow for protection, a light covering of leaves, or salt hay, or the branches of evergreens will be of great service. This covering should not be placed over the plants until the ground is frozen, say from the middle of November till the beginning of December. The covering should be removed in spring just as soon as the plants begin to grow.

The sorts marked (P) are pistillate, and will not fruit alone, but should be planted beside some staminate or perfect flowered variety.

Talbot (P.) Roundish conical form, bright red color, large and of delicious flavor, \$2 50 per 100 .

Marshall. A worthy favorite, the fruit is very large, deep crinison color, and of extra quality and flavor. Late. $\$ 2.50$ per Ico.

Clyde. Large, roundish conical form, bright scarlet, good quality. Season medium, $\$ 2.50$ per 100 .

Gladstone. Plants of vigorous giowth and productive, fruit as large as Sharpless, quality very good. Early, \$2.50 per roo.

Belmont. A general favorite for market and home use. Large, dark crimson fruit. Late, $\$ 2.50$ per 100 .

Nick Ohmer. Large, conical, dark red fruit of excellent flavor. Very suitable for winter forcing under glass. Season medium, $\$ 2.50$ per 100 .

Rio. A large, crimson, productive sort, of good quality. Early, \$2.50 per 100.

Haverland (P.) A fine berry, color light red. Large, and of good quality, very productive. Early, \$2.50 per 100.

St. Joseph Everbearing. Bears abundantly throughout the season. The berries are of medium size, bright red color, and siveet aromatic flavor. \$3.00 per 100 .

\section{LAYER STRAWBERRY PLANTS.}

Ready for shipment about the first of October. The plants we furnish are well rooted layers from the open ground. The price for the foregoing sorts and Bubach No.5 (P), Brandywine, Enormous (P), Gandy, Glen Mary, and Leader is $\$ \cdot$.0o per 100. 


\section{Hardy Herbaceous Perennials.}

These plants grow in beauty, size and value year by year. They require less care than most desirable flowering plants, and are adapted for nearly every condition. The months named indicate the time of flowering of each.

Achillea "The Pearl." Pure white, double. 2 feet

Alyssum Saxitile Compactum. Beautiful yellow flowers in Spring. 6 inches

Anemone Japonica Rosea. Dark pink flowers in August and September. 2 feet “ Alba. Beautiful white. 2 feet

Anthemis Tinctoria. (Yellow Marguerite.) Flowers May and June. 2-3 feet

Aquilegia Chrysantha. Rich yellow. July. 3 feet

"“ Cœrulea Hybrida. Shades of blue, white, pink, yellow, etc. 2-3 feet

Armeria Laucheana. (Sea $\left.P_{i n k}\right)$. Bright rose. May to fro t. 9 inches

Aster Formossima. Rosy-purple. September. 4 feet.

“ Nova Angliae Rosea. Pink New England Aster. 3 feet.

Boltonia Latisquamæ. Clear lilac. September. 4 feet

Campanula Grand flora (Platycodon.) Very dark blue. August-St ptember. 2-3 feet

“Persicifolia Grandiflora (Peach leaved Bell flower). Porcelain blue. June to

August. $2-3$ feet

Centaurea Montana. Colors red, white, blue and pink. Summer. $1 \frac{1}{2}$ feet

Coreopsis Grandiflora. Golden yellow. Summcr. 2 feet

Delphinium Chinensis. Intense blue. Summer. 2 feet

“ Formosum. Blue, white centre. Summer: 3 feet

“ Hybridum. Various shades of blue. Summer. 2 feet

Eulalia Japonica Variega!a. A stately grass with green and white leaves. 6 feet.

Gypsophila Acutifolia. Flowers tinted with pink. Larger and later than the Paniculata. 4 feet .

Gypsoptila Paniculata. Small white flowers in great profusion. Summer. 2 feet

Helenium Autumnale Superbum. Bright yellow. August. 5 fcet

Helianthus Deca-etalous. Bright yellow. Simmer. 5 feet

Heliopsis Pitcherii. Golden yellow. July-October. 6 feet

Hemerocallis Disticta Plena. Double terra-cotta flowers. Summer. 3 feet

“ Dumortieri. Orange. Summer. 2 feet

“ Graminifolia. Yellow flowers. Grass-like foliage. Summer. 2 fect

Heuchera Sanguinea. Bright red flowers. Handsome foliage. Summer. $3 \frac{1}{2}$ feet

"Alba. Floivers white, otherwise same as above

Hibiscus Militaris. Salmon pink, 5 inches across. Alıust-September. 2-3 feet

“ Moscheutos Crimson Eye. White with crimson eye. August-September. 3-+ft

Iberis Corræf.lia (Perennial Candytuft.) Flowers white, foliage evergreen. May-June. 6-12 inches

Iris Germanica. Named sorts. White, purple, marbled, etc. Jrne. 2 feet

“ Kæmpferii (Japanese Iris). Named sorts. Beautiful colors̀. June-July. 2 feet

"6 "، Mixed

“ Pumila. White, blue, yellow. June-July. 6 inches.

“ ". Mixed

Lathy rus Latifolius (Perennial Pea.) Bright red. Summer. 5 feet

" " Albus. White, otherwise like above

Liatris Pycnostacha. Lavender purple. Summer. 6 feet

Lychnis Chalcedonica. Brilliant scarlet. Summer. 2-3 feet

“ Diut na Rubra Plena. Deep purplish-red. Summer. 2-3 feet

“ Flos=cuculi Semperflorens. Delicate rose. Summer. $1 \frac{1}{2}$ feet

Lathryum Roseum Superbum. Rosy-red. Summer. 2-3 feet

Monarda Didyma. Brilliant scarlet. Foliage sweet scented. Summer. 2-3 feet

Myo:ot is Palustris Semperflorens. (Forget-me-not). Light blue. Summer

Enothera Youngii. Clear yellow. 2 inches in diameter. June-August. 2 feet.

Phlox Subulata. (Moss Pink). Various colors. May. 6 inches

“ Suffruticosa. In variety. Many colors. June-August. 1-2 feet

“Decussata “ " " A utumn blooming. 2-3 feet

Pyrethrum Roseum Hybridum. Colors range white to dark crimson. Summer. 2 feet

"Uliginosum. Pure white. September. 4 fect

Rudbeckia Golden Glow. Double golden yellow. August-September. 5 feet

Scabiosa Caucasica. Lilac blue. Summer. 2 feet

Spireea Palmata. Crimson flower. Palm-like foliage. Summer. 3 feet

Veronica Longifolia Subsessilis. Blue ftowers. August-September. 3 feet.

The prices attached are very low for strong plants, but we will furnish one plant of each of the 56 kinds named for $\$ 8.00$ net. 


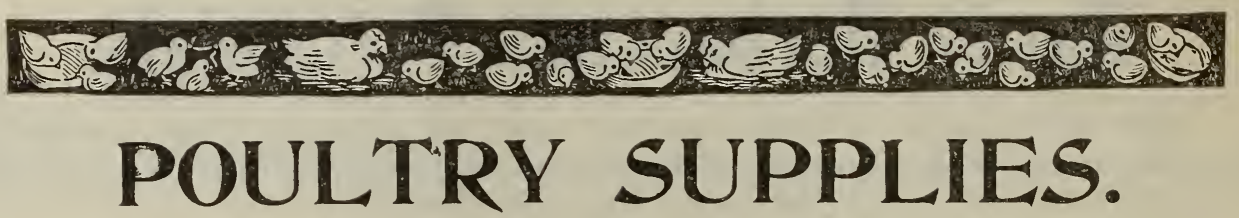

(Prices subject to change.)

All Poultry Supplies are specialties with us, and it is a fact, generally known, that we carry the most complete line of the Best Goods to be found anywhere in the United States.

We, however, call especial attention to the following Three Feeds.

Breck's Poultry and Saine Meal. A meat, blood and bone preparation niade from a German formula and originally introduced by us to the Poultry Keepers of the U.S. in iSg2. It is the best ani mal inatter food on the market today and is used and endorsed by thousands of Poultry men from Maine to California. If you have not yet tried it you should do so at once. 10o lb. baig, $\$ 225 ; 50 \mathrm{lb}$. bag, $\$ 1 . j 0$; trial bag (a month's supply for 30 hens), $\$ 1.00$.

Breck's Cereal Chicken Feed. This is a com bination of cracked and othervise specially cut and prepared grains ia the proportions that long experi ence in raising and feeding chicks for profit has sh'wn to produce the best iesults. It is in 1 tself a sufficient food to carry the chicks from the shell to maturity in the shortest possible time and with best results as to health, 110 inatter whether the birds are wanted for broilers, roasters or early laying. It is used in large quantities by the most successful Poul. try men in the country, and is without doubt the best cereal preparation on the market. $50 \mathrm{lb}$. bag, $\$ 1.25$; $100 \mathrm{lb}$. bag, $\$ 2.00$. Net.

Breck's Alfalfa and White Clover and Clover Meal. Cut Clover and Clover Meal are so well known and generally used that we need not say a word regarding their value as part of the daily rations. Much of the material, however, sold under these names c ontains but a small percentage of clover, or consists of the clover stalks from which a crop of seed has been harvested and consequently is simply woody fibre and of little value for poultry.

Knowing all this we have had grown especially for us several fields of Alfalfa, WThite and Red Clovers. These mixed in the right proportion form a clover ration in every way superior to others on the market. We exercise care to have the several crops cut at the proper stage of growth and under rather than overcured. IVe feel sure our many poultry keeper friends will appreciate the excellence of these clover mixtures and see when buying that spurious brands or inferior grades are not substituted for them. A reasonable trial only is necessary to demonstrate their superiority. When buying be sure to ask for and get only Breck's Alfalfa and White Clover and Breck's Alfalfa and White Clover Meal. Per $50 \mathrm{lb}$. bag, $\$ 1.25$; $100 \mathrm{lb}$. bag, $\$ 2.00$. Net. Special price per ton upon application.

Ground Oyster Shells. $100 \mathrm{lb}$. bags, $65 \mathrm{cts}$. per 100 lbs.; in bbls. of 250 lbs., 65 cts. per $100 \mathrm{lb}$.

Mica Crystal Grit. 50 lb. bag, 65 cts.; $100 \mathrm{lb}$. $90 \mathrm{cts}$.

Cracked Poultry Bone. Per bbl. of about 200 Jbs., $\$ 2.50$ per $100 \mathrm{lbs}$.

Bone Meal for Poultry and Cattle. $50 \mathrm{lb}$. bag, $\$ \mathrm{r} .50 ; 100 \mathrm{lb}$. bag, $\$ 2.50$; per bbl. of about $200 \mathrm{lbs}$. $\$ 2.50$ per $100 \mathrm{lbs}$.

Flour of Bone. $50 \mathrm{lb}$. bags, $\$ 1.50$; $100 \mathrm{lb}$. bags, $\$ 2-50$; per bbl. of about $200 \mathrm{lbs}$., $\$ 2.50$ per $100 \mathrm{lbs}$.

Ground Beef Scraps. $50 \mathrm{lb}$ bags, $\$ 1.50$; $100 \mathrm{lb}$. bags, $\$ 2.50$.

Wheat. $\$ 1.50$ to $\$ 2.00$ per $100 \mathrm{lbs}$., according to quality. Net.

Wheat Screenings. $\$ 1.25$ to $\$ 1.50$ per $100 \mathrm{lb} . \mathrm{bag}$, according to quality. Net.
Green's Poultry Food. A mixture of granulated cereals, grand as a scratching 100 for both chicks and adult fowls. Per $50 \mathrm{lb}$. bag, $\$ 1.25$; $100 \mathrm{lbs}, \$ 2$.

Spratt's Food. The celebrated English prepara. tion, nothing equals it for young chicks. $50 \mathrm{lb}$. bag, $\$ 3.00 ; 100 \mathrm{lbs}$; $\$ 5.50$.

Barley. So cts. perbu. Net.

Buckwheat. $90 \mathrm{cts}$. per bu. Net.

Peas. Small white Canada, $\$ 1.25$ per bu. Net.

Sunflower. I.arge Russian, \$1 50 per bu.

Millet. Golden, for chickens, $\$ 1.25$ per bu. of 50 lhs. Net.

Hemp, Large Russian. Much fed to pigeons and fowls that are being fattened for the table, $\$ 1.75$ per bu. of $40 \mathrm{lbs}$. Net.

Kaffir Corn, or White Sorghum. Per roolb. bay, $\$ 1.50$. Net.

Brcck's Eureka Egg Food. This preparation stands without a rival, as hundreds of those who have used it testify. It aids digestion, prevents and cures many diseases common to fowls, and although the best food known to produce (ggs, it does not destroy the fertility of the egg. Sample box by inail on receipt of 25 cents. I lb. box, 25 cents each if by inail, 40 cents each; $2 \frac{1}{2} 1 \mathrm{~b}$. box, 50 cents each; by mail, $\$ 1.00$ each; $6 \mathrm{lb}$. box, $\$ 1.00 \mathrm{cach} ; 10 \mathrm{lb} \mathrm{bnx}$, $\$ 1.50$ each; $25 \mathrm{lb}$. kegs, $\$ 3.50$ each. These larger sizes can be sent cheaper by express than by mail.

Rust's Egg Producer. I lb. box, 25 cents each, if by inail, 44 cents; $2 \frac{1}{2} 1$ b. box, 50 cents each, if by mail, $\$ 1.00 ; 6 \mathrm{lb}$. box, $\$ 1.00 ; 10 \mathrm{lb}$. box, 1.50; $25 \mathrm{lb}$ liegs, \$3.50. These larger sizes can be sent cheaper by express than by mail.

Rust's Haven's Roup Pills. These pills act directly on the glands and mucous membrane, allaying all tendencies to fever and carrying off all niorbid matter from the system. Box of $4 S$ pills free, by mail, 25 cents.

Rust's Haven's Climax Condition Powder. Small package, 25 cents, if by mail, 50 cents; $2 \mathrm{lb}$ box, 50 cents, if by mail, 85 cents; $5 \mathrm{lb}$. box, equal to 6 25-cent packages, $\$ 1.00$. (This size is too heavy tor mailing and can be forwarded cheapest by express.)

F. P. C. Chick Manna. 1 lb. 1o cts.; 5 lbs. 40 cts.; 15 lbs. $\$ 1.10 ; 60 \mathrm{lbs} . \$ 4.20$. Net.

Charcoal, Granulated. Per Ib. 7 cts.; per 100 lbs. $\$ 5$ 50. Net.

Charcoal, Powdered. 6 cts. per lb.; per $100 \mathrm{lbs}$. $\$ 4.5 \mathrm{C}$. Net.

Copperas. (Green Stone.) 2 cts. per lb. Net.

Carbolic Crystallized. 50 cts. per bottle, bottle included. Net.

Carbolic Acid S lution. 40 cts. per pint bottle, bottle included. Net.

Carbolic Purifying Powder. Trial pkg., 25 cts. if by mail, $40 \mathrm{cts} ., 6 \mathrm{lb}$. pkg., $\$ 1.00$, if by mail, $\$ 2.00$.

Dalmation Insect Powder. Per lb. 40 cts. It by mail, $50 \mathrm{cts}$. 


\section{POULTRY SUPPLIES.-Continued.}

Death to Lice. 15 oz. box, 25 cts., jf by mail $40 \mathrm{cts} ., 3 \mathrm{lb}$. pkg. 50 cts., by mail $\$ 1.00 .100 \mathrm{oz}$. pkg., $\$ 1.00$, if by mail, $\$ 2.00$.

Death to Lice, Special. A preparation containing all the qualities of the famous "Death to Lice Powder," but which is soluble in Kerosene oil and ran be used to paint or spray roosts and interiors of poultry houses. I lb. box. 25 cts., if by mail, $40 \mathrm{cts}$.

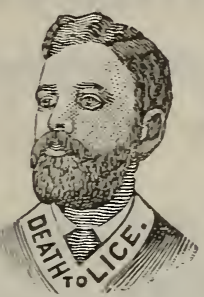

Death to Lice Ointment. For use on young chicks. Per box, 10 and 25 cts.

“o. E. C." Lice Powder. An excellent article. It not only is death to all insects but acts as a power ful yet pleasan: disinfectant. 25 and 50 cts. per box. Net.

P. D. Q. Powder. A valuable preparation that not only destrors and prevents insects of all kinds on fowls, but drives away quickly all sorts of insects that pester the housewife. It is useful for a hundred and ore purposes and not the least among them is that of disinfectant. Per package, 25 and 75 cts. Net.

Rice's Lice Paint. For poultry and all domestic animals. Kills ticks, mites, lice, fleas and bed-bugs. Easy to apply. 2 qt. can, 5o cts.; 1 gal. can, $75 \mathrm{cts}$; 5 g:als., $\$ 3.00$. Net.

Tobacco Dust. An exceedingly fine powder. Valuable as an insecticide. Per 1 b., 5 cts. Net.

Tobacco Stems. Used to mix with nest material, fumigating, etc. Per Jb , 5 cts.; per bale, $\$ 2.50$. Net.

Suipho=Napthol. This preparation, originated by the Jate Dr. Cabot, is recommended for a great many purposes. It cleans and heals all sorts of cuts. bruises and scres. It is sure death to all kinds of bacteria and insects and is unsurpassed as a disinfectant. For domestic animals, poultry and poultry houses it is the thing. 50 ct. bottle makes 10 gals.; $\$$ : oo can, 5 o gals. solution. Net.

Oil of Tar. A new coal tar preparation, some. what similar to Sulpho-Napthnl. Per qt., 25 cts.; $\frac{1}{2}$ gal., 5octs.: 1 gal., \$1.00. Net.

Veterinary $\mathrm{X}=\mathrm{Zalia}$. A purcly regetable preparation, contains no alcohol or poisonous ingredients. It may be applied to a raw surface or even poured into the eve of an animal without causing pain. 1t cures G.Llls, Scratches, and Surface Inflammation of every description. Per large bottle, \$1.25.

Plasier. Land. A raluabie absorbent, when mixed with the droppings it deodorizes, also en. hances their value as a ferilizer. Per $100 \mathrm{bag}, 50 \mathrm{cts}$. perton, \$\$.00. Net.

Nest Eggs, China. Per doz., $40 \mathrm{cts}$. Net.

Medicol Nest Eggs. These are medicated eggs but entirely different from anything that has hitherto been offered. They can be cleaned without injury, are lasting, effective, and appreciated by chickens and adult fowls. No hen should be set without one of these in the nestas a preventitive of vermin. One placed in a bird cage keeps it sweet and the bird free from insects. They drive awav lice from pot plants, prevent moths from attacking furs or other clothes when packed away, and are also valuable as a disinfectant. Io cts. each; \$I oo per doz.

Bellows, Spraying. $\$ 1.25$ to $\$ 2.25$.

Bellows, Houchin's Patent Powder. $50 \mathrm{cts}$, Tots., $\$ 1.10$ and $\$ 1.50$.

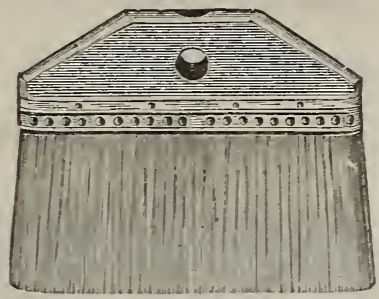

Brushes, White= wash. Tampico centre, bristles outside. 'Each, 7 in., 50

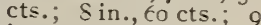
in., 75 cts.

Nests, Wire. Strong and clean. Each, 5o cts.

Leg Bands. The f a mous Phon ix, superior to all others. Numbered to order. Per doz. $25 \mathrm{cts}$.; per 100, $\$ 1.50$.

Leg Bands, Aluminum, for Pigeons. Seam. less, per doz, 40 cts.: per 100, \$2.50. Open, per doz. 30 cts. ; per I $00, \$ 1.50$.

Lèg Bands, Aluminum, for Poultry. Per doz., 30 cts.; per 100, \$r.50.

Guns, Insect Powder. 2 oz. size, $15 \mathrm{cts}$. each.

\section{STONE DRINKING FOUNTAIN.}

This fountain is of the best patent stoneware, and is very desirable.

$\frac{1}{2}$ gallon each

Net Price, $\$ 0.35$

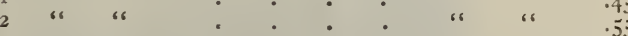

"E. H. M." Stone Fountains. Made of glazed stoneware, in two pieces; a saucer and an inverted cup, finished off on top to prevent roosting. Strong, cheap, easily cleaned and quicklv filled. The best stoneware fountain vet offered. The one quart size is especially suitable for pigeons. I qt., $30 \mathrm{cts}$.; 2 qt., 3 cts.; I gal., . 15 cts. Net.

Sanitary Fountain. Square in form, made of galvanized iron, in two pieces, easilv cleaned and filled. 1 gal., 75 cts.; 2 gal., $\$ 1.00 . \quad N e t$.

\section{HUB DRINKING FOUNTAIN.}

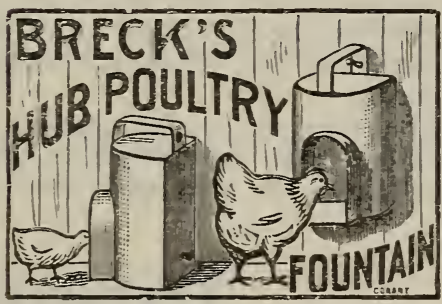

This fountain is made of the best galvanized iron, is very strong, easily cleaned, quickly filled and is iqually service able for both chickens and adult fowls (see cut). This founta in is rastly

superior to a! 1 others.

I gallon

Price, each, \$o.75

Roofing Material. We carry in stock two and three ply Tarred Roofing, Rubcroid Roofing, Red Rop= Roofing Paper, etc., \$r.25 to $\$ 2.25$ per square.

Caporizing Instruments. TVe carry a full line of the best makes and approred patterns. Prices, from $\$ 2.50$ to $\$ 7.00$ per set. Book of instructions furnished with each set.

\section{Knives, French Poultry Killing.}

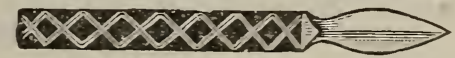

When this knife is properly used there is no complaint as to imperfect bleeding of broilers or roasters. By mail 5o cts. 


\section{Prairie State Incubators and Brooders.}

JOSEPH BRECK \& SONS (Corporation),

New England Agents.

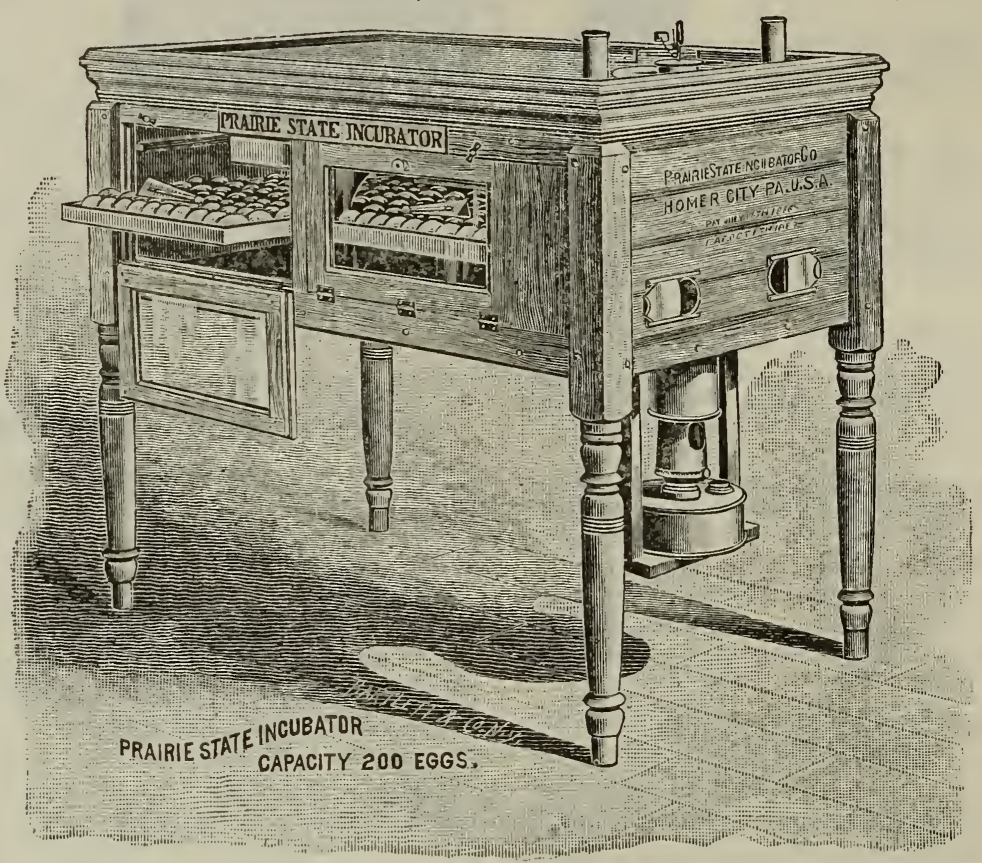

The only machines made with which the amateur or professional can always be sure of success are the Genuine Prairie State Incubators and Brooders made at Homer City, Penn. Do not be deceived by the wordy advertisements of other makers, but investigate these machines thoroughly.

We guarantee their successful operation. For the coming season a large, beautiful catalogue containing many colored plates, up-to-date information, testimonials, etc., is now ready for distribution. If interested, send for this work. We will send it by mail, postpaid.

\section{ITIPORTANT.}

Before purchasing elsewhere write to us for circulars and prices of anything you may be in want of relating to the poultry business. We know we can please you as to prices and quality of the goods offered.

In addition to the articles shown in this catalogue we carry in stock the following, viz. :

\section{Mann's Green Bone Cutters, Wilson Grinding Mills, Thayer Brooder $=$ House Heaters, Shell and Corn Mills, Clover Cutters, Caponizing Tools, Poultry Netting,}

and many other articles which our space does not permit us to menticn. Don't fail to write for information. 


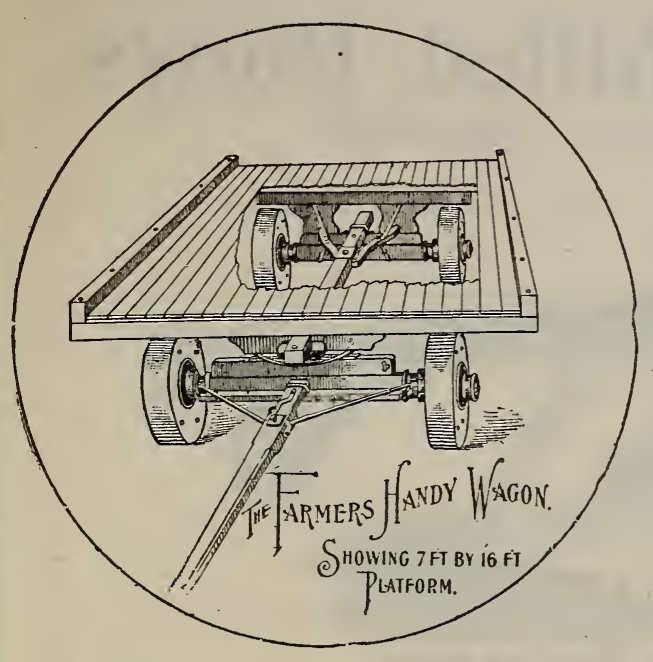

\section{FARMER'S HANDY W GON.}

All thrifty farmers have for some time felt the necessity for a low-down, wide-tirc, sho:t-turning, broad-platform wagon for general use upon the farm This demand, until the first "IIandy Wagon" was built, had never been met. This wagon has been on the market for eight years, and it has reached as high a state of perfection as ingenuity and the criticism of its many users can effect. The No. 9 Farmer's IIandy Wagon is the latest, and we believe it to be the best gencral purpose two-horse farm truck made. It, in connection with our platform, combines all the advantages which are sought in a faim truck.

No.y Farmer's Handy Wagon, Our net price, $\$ 35.00$ Platform Frame for No. $9 \quad 6 \frac{1}{2} \mathrm{x}_{13} \mathrm{ft}$. " “ 7.00 Complete descriptive catalogue mailed on application. Not included in our special offers.

UNION LAWN FENCE.

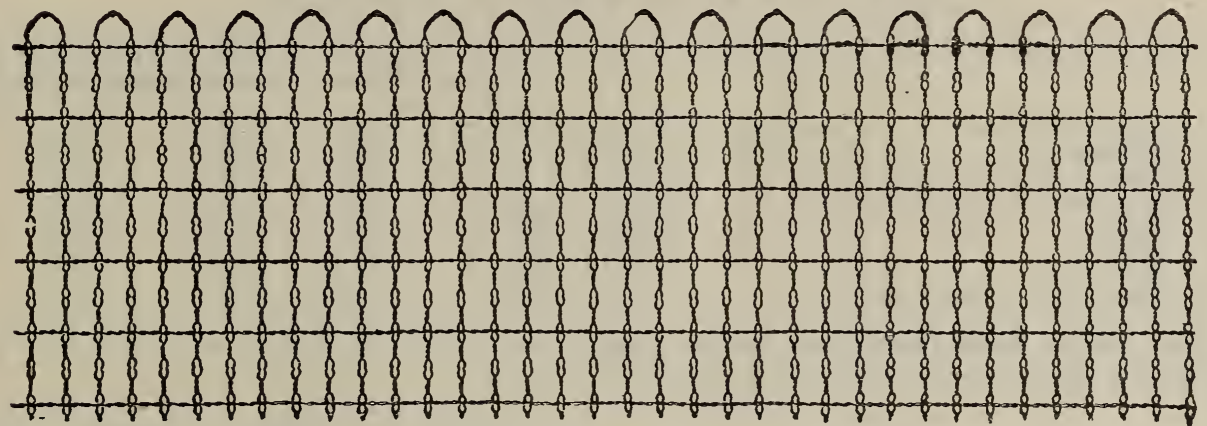

For Lawns, Division Fences, Churches, Cemeteries, etc., stronger, neater in appearance and less expensive than unsightly wood fence.

\section{Standard Fence.}

Pickets $2 \frac{5}{8}$ in. apart.

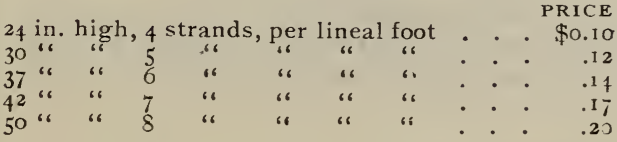

\section{Close Mesh Fence.}

$$
\text { Pickets I } \frac{3}{1} \text { i:ı. apart. }
$$

$2+$ in. high, 4 strands, per lineal foot

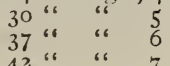

50 “"

The pickets are made of two No. 12 galvanized steel wires, formed as shown in cut, with two twists between opening in the picket.

The cables are made of two No. 14 galvanized steel wires, spaced $6 \frac{1}{2}$ inches apart. These are twisted between the legs of the pickets which hold the flat side of the picket in the plane of the fence and at the same time prevent the cables from slipping on the picket.

The fence is very strong, fits uneven ground and will follow an incline as well as a level surface.

\section{Standard Rolls, 300 feet. Special Lengths made to Order.}

Also, Posts, Gates and Fittings for Union Lawn Fence, and several st: les of Field, Farm and Park Fencing. Catalogues and estimates on application.

\section{POULTRYMEN, ATTENTION !}

A year ago we announced a new and up-to-date edition of our " Points for Poultry Raisers," which was so favorably received that we were obliged to print several editions before A pril rst, Igor. We will publish this fall, a revised "Points for Poultry Raisers" which will contain new and valuable matter of great interest to all owners of Poultry. This work will be mailed on application. 


\section{The Oliver Chilled Plows.}

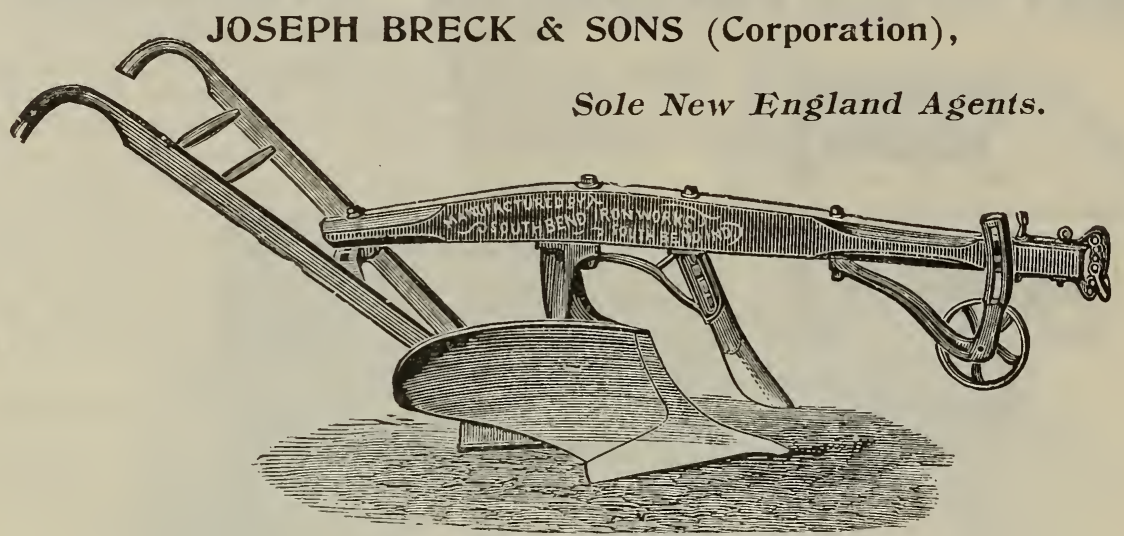

No. 40 Oliver Plow, with Wheel and Jointer.

For Fall Plowing the Celebrated Oliver Chilled Plow leads all others.

Our prices are right and satisfaction is guaranteed.

\begin{tabular}{|c|c|c|c|c|c|c|c|c|}
\hline & & & & & Weight. & Plain. & $\begin{array}{l}\text { With } \\
\text { Wheel. }\end{array}$ & $\begin{array}{l}\text { With wheel and } \\
\text { Jointer or Cutter. }\end{array}$ \\
\hline $\begin{array}{r}\text { No. A. } \\
\text { B. } \\
10 . \\
13 . \\
19 . \\
20 . \\
\text { E. } \\
40 .\end{array}$ & $\begin{array}{l}\text { Light One-Ilorse } \\
\text { Medium “. } \\
\text { Heavy " } \\
\text { Very Light Two-Horse } \\
\text { Light } \\
\text { Medium } \\
\text { Heavy } \\
\text { Heavy Two or Three-Ho }\end{array}$ & $\begin{array}{l}\therefore \\
\therefore \\
\therefore \\
\therefore \\
\text { orse: }\end{array}$ & $\begin{array}{c}\text { Furrow, } \\
\text { "6 } \\
\text { "6 } \\
\text { "6 } \\
\text { "6 }\end{array}$ & 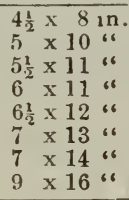 & $\begin{array}{rl}50 & \mathrm{lbs} \\
65 & \text { “6 } \\
70 & \text { “6 } \\
80 & \text { “6 } \\
100 & \text { “6 } \\
110 & \text { “6 } \\
125 & \text { “6 } \\
130 & \text { “6 }\end{array}$ & $\begin{array}{r}\$ 4.50 \\
6.00 \\
7.00 \\
8.00 \\
8.50 \\
9.00 \\
9.50 \\
9.50\end{array}$ & $\begin{array}{r}\$ 5.25 \\
6.75 \\
7.75 \\
8.75 \\
9.50 \\
10.00 \\
10.50 \\
10.50\end{array}$ & $\begin{array}{r}\$ 6.75 \\
8.25 \\
9.25 \\
10.25 \\
11.50 \\
12.00 \\
12.50 \\
12.50\end{array}$ \\
\hline
\end{tabular}

The Oliver Side Hill Plow works equally as well on level land as on side hill, and contains all the latest improvements in side hill plows.

\begin{tabular}{|c|c|c|c|c|}
\hline & & Weight. & Plain. & Complete W.\&J. \\
\hline $\begin{aligned} \text { No. 52. } & \text { Light One-Horse } \\
57 . & \text { Med um Two Horse } \\
56 . & \text { Heavy }\end{aligned}$ & $\begin{array}{cl}\text { Furrowv, } & 6 \times 11 \\
\because & 6 \times 13 \\
\text { ، } & 6 \times 14 \\
\end{array}$ & $\begin{array}{l}100 \mathrm{lbs} . \\
140 ، \\
160 ،\end{array}$ & $\begin{array}{r}\$ 1000 \\
13.00 \\
12.00\end{array}$ & $\begin{array}{r}\$ 16.00 \\
15.90\end{array}$ \\
\hline
\end{tabular}

On, extra share given with each plow.

Beware of imitation plows and extras, claiming to be the genuine Oliver or equally good. The genuine plows and repairs, direct from the factory, are for sale in New England only by us and our authorized agents. All others are spurious, and can not be relied upon to fit well or do good work.

\section{FALL GOODS.}

Our stock of Fall Goods, consisting of Ross Ensilage Cutters, Hay Cutters, Gasoline Engines, Horse Powers, Cider Mills, Wine Presses, Cob Mills, Potato Diggers, Root Cutters, Corn Shellers, Fan Mills, Farmers' Kettles, Etc., Etc., is very complete. Circulars, prices, etc., mailed on application.

\section{CATLOGUE.}

Our Illustrated Catalogue of Agricultural Hardware, Implements, Machines and Wooden ware (second edition), size $81 / 2$ X I I in., contains $384 \mathrm{pp}$. and 1500 illustrations, making it the most complete, up-to-date catalogue tver issued.

As this book is too large and valuable to send by mail, we can only send it free tn ons customers who order goods shipped them by express or freight. To others interested we will send it express prepaid on receipt of $25 \mathrm{cts}$., and this sum may be deductea from amount of the first purchase of Seed, Bulbs, Plants or Hardware. 


\section{SPECIAL OFFERS.}

\section{CARRIAGE PAID OR 10 PER CENT. DISCOUNT ALLOWED.}

We make the following offer's on all order's made "p from our HOLLAND BLLB AND PLANT CATALOGLE FUR 1901, at the net cash prices therein stated (exrept rs moted). SENT US BI MAIL OR EXPRESS, AC'OMPANTEI) BY CASH.

OFFER No. 1.

We vill send GOODS PREPAID by Mail, Express, or Freight, as ue may deem advisable, TO ANI CITI OK TUUN IN NEW ENGLAND.

\section{OFFER No. 2。}

We DELIVER all Bulbs at single and dozen prices quoted in this catalngue, to any POST-OFFICE in the United states, except the few heavy Species which are marked "subject to special offer No. 3 only.",

OFFER Vo. 3.

On all orders (except as noted) WHERE CUSTOMIERS PAY TRANSPORTATION CHARGES THEMSELVES, UE will allow A DISCUUNT OF TEN PER CENT.

\section{PLEASE REMEMBER.}

That orders sent in early SECURE THE FIRST SELECTIONS.

That our SPECIAL OFFERS are POSTTIVELY LIIIITED to ORDERS BI MAIL O EYPRESS ACCOMPAVIED BY CASH, postril note, draft on Vew York or Bostor, stcmps, express or post-office money order.

That "Specirl offers Nos. 2 and 3" are especially advantageous to PARTIES LIVING OCTSIDE of New England; when goods ale not mailable, in a majority of crses the $10 \mathrm{per}^{2}$ cent. discount will off'set transportation charges.

\section{PLEASI NOTE.}

We offer such extraordinamy inducements for orders sent us by mail or express, accompanierl by casth, beculse ue cru execute them in the quiet of ous mail order depritment with promptriess, dispatrh, and with goods of the highest excellence, and increase the volume of our business without impairing the efficiency of its service.

OUR 1902 General Catalogue will be published early in Junuary. A zopy will be mailed free to all applio cants, and to customers of this year without ordering it.

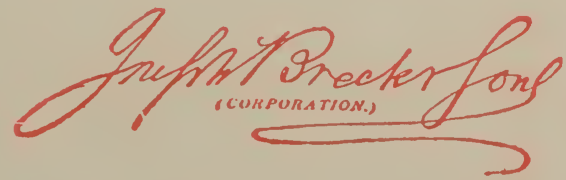




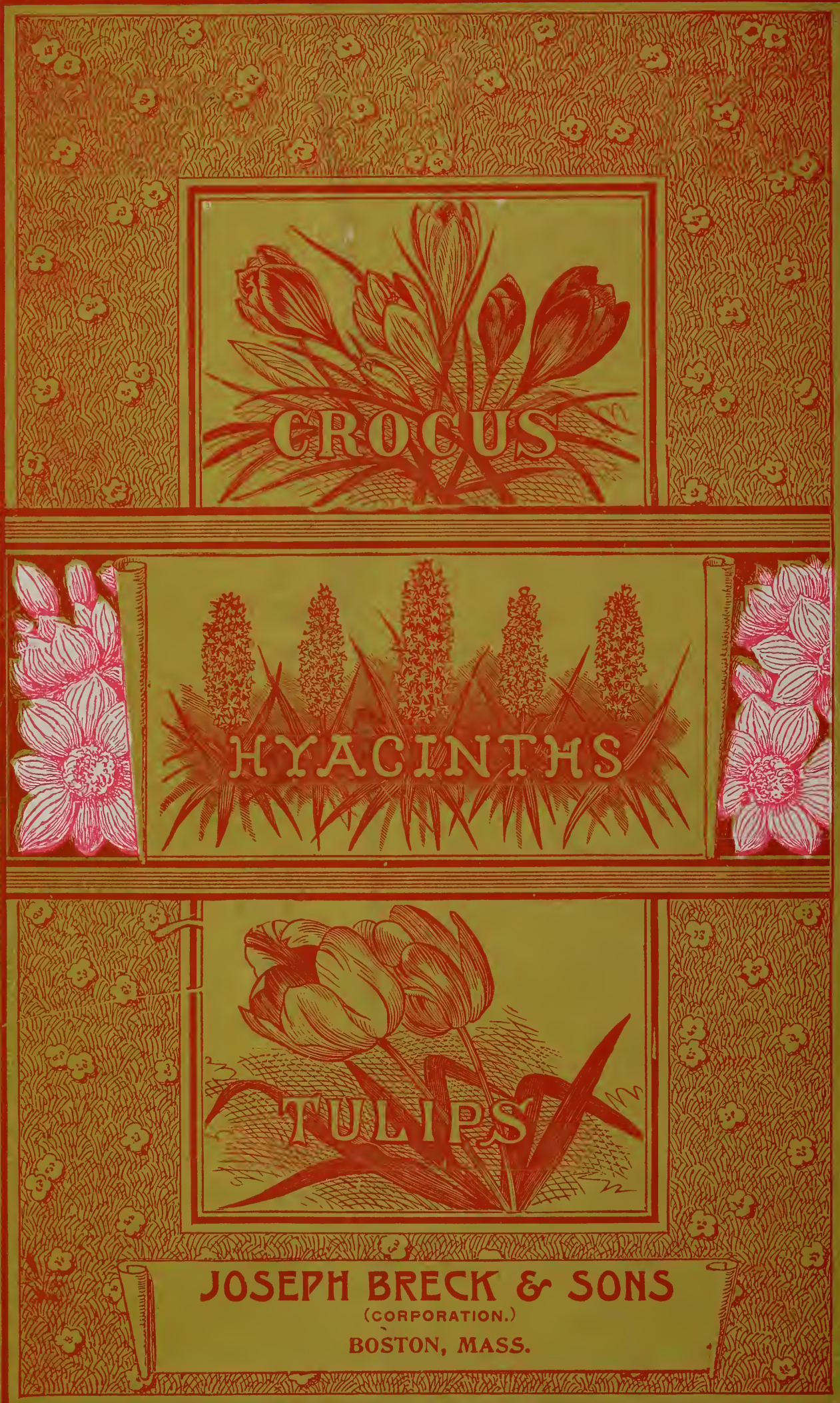

